Proceedings of the Prehistoric Society 86, 2020, pp. 13-42 (C) The Author(s), 2020. Published by Cambridge University Press on behalf of The Prehistoric Society. This is an Open Access article, distributed under the terms of the Creative Commons Attribution licence (http://creativecommons.org/licenses/by/4.0/), which permits unrestricted re-use, distribution, and reproduction in any medium, provided the original work is properly cited. doi:10.1017/ppr.2020.8 First published online 16 September 2020

\title{
New Evidence for Upland Occupation in the Mesolithic of Scotland
}

\author{
By C.R. WICKHAM-JONES ${ }^{1}$, G. NOBLE ${ }^{1}$, S.M. FRASER ${ }^{2}$, G. WARREN ${ }^{3}$, R. TIPPING ${ }^{4}$, D. PATERSON ${ }^{4}$, W. MITCHELL $^{5}$, \\ D. HAMILTON ${ }^{6}$ and A. CLARKE ${ }^{7}$
}

\begin{abstract}
This paper discusses the evidence for periodic human activity in the Cairngorm Mountains of Scotland from the late 9 th millennium to the early 4th millennium cal BC. While contemporary paradigms for Mesolithic Europe acknowledge the significance of upland environments, the archaeological record for these areas is not yet as robust as that for the lowland zone. Results of excavation at Chest of Dee, along the headwaters of the River Dee, are set into a wider context with previously published excavations in the area. A variety of site types evidences a sophisticated relationship between people and a dynamic landscape through a period of changing climate. Archaeological benefits of the project include the ability to examine novel aspects of the archaeology leading to a more comprehensive understanding of Mesolithic lifeways. It also offers important lessons in site survival, archaeological investigation, and the management of the upland zone.
\end{abstract}

Keywords: Mesolithic, uplands, lithics, climate change, radiocarbon dating, Mesolithic-Neolithic transition, landscape management

Interpretations of the Mesolithic argue for the sophisticated use of a variety of landscapes, yet the exigencies of survival and recovery mean that research in north-west Europe has tended to focus on the coast and the lower reaches of river valleys. Activity in the uplands has been recorded, for example in the Alps (see Fontana et al. 2016 and other papers in special edition of Quaternary International 423, 2016) and

${ }^{1}$ Department of Archaeology, School of Geosciences, The University of Aberdeen, St Mary's Building, Elphinstone Road, Aberdeen, AB24 3FX, Scotland c.wickham-jones@ mesolithic.co.uk

${ }^{2}$ The National Trust/University of Aberdeen, Rowallane Stableyard, Saintfield, Co. Down, BT24 7LH, Northern Ireland

${ }^{3}$ School of Archaeology, University College Dublin, Dublin 4 , Ireland

${ }^{4}$ Biological \& Environmental Sciences, School of Natural Sciences, University of Stirling, Stirling, FK9 4LA, Scotland.

${ }^{5}$ Geography \& Environmental Science, University of Dundee, Dundee DD1 4HN, Scotland

${ }^{6}$ Scottish Universities Environmental Research Centre (SUERC), Rankine Avenue, East Kilbride, G75 0QF, Scotland ${ }^{7}$ Rockville Lodge, North Berwick, East Lothian, Scotland.
Fennoscandia (Bang-Andersen 1987) and Bailey suggests that expansion to new environments such as upland areas should be seen as a 'defining characteristic' of the Mesolithic in many regions of Europe (2008, 357). However, our understanding of Mesolithic lifeways in Britain is still hampered by this evidential gap. While upland sites are reasonably common in some areas (Spikins 2002; Preston 2013), in Scotland, a country dominated in some regions by its highlands, such sites are still rarely documented, isolated, and poorly contextualised (Edwards 1996; Atkinson 2016).

This scarcity of sites is perhaps unsurprising. In Scotland, upland areas are 'amongst the most intransigent in terms of standard survey approaches' for identifying Mesolithic material (Saville \& WickhamJones 2012, 58): peat cover is extensive, slope and soil erosion can be dramatic (Sugden 1971; RobertsonRintoul 1986), and modern development and agriculture, with their opportunities for prospection, are rare. Yet because upland sites occur in areas where the impact of modern land use practices has been relatively modest, their potential integrity is high, offering detailed evidence 


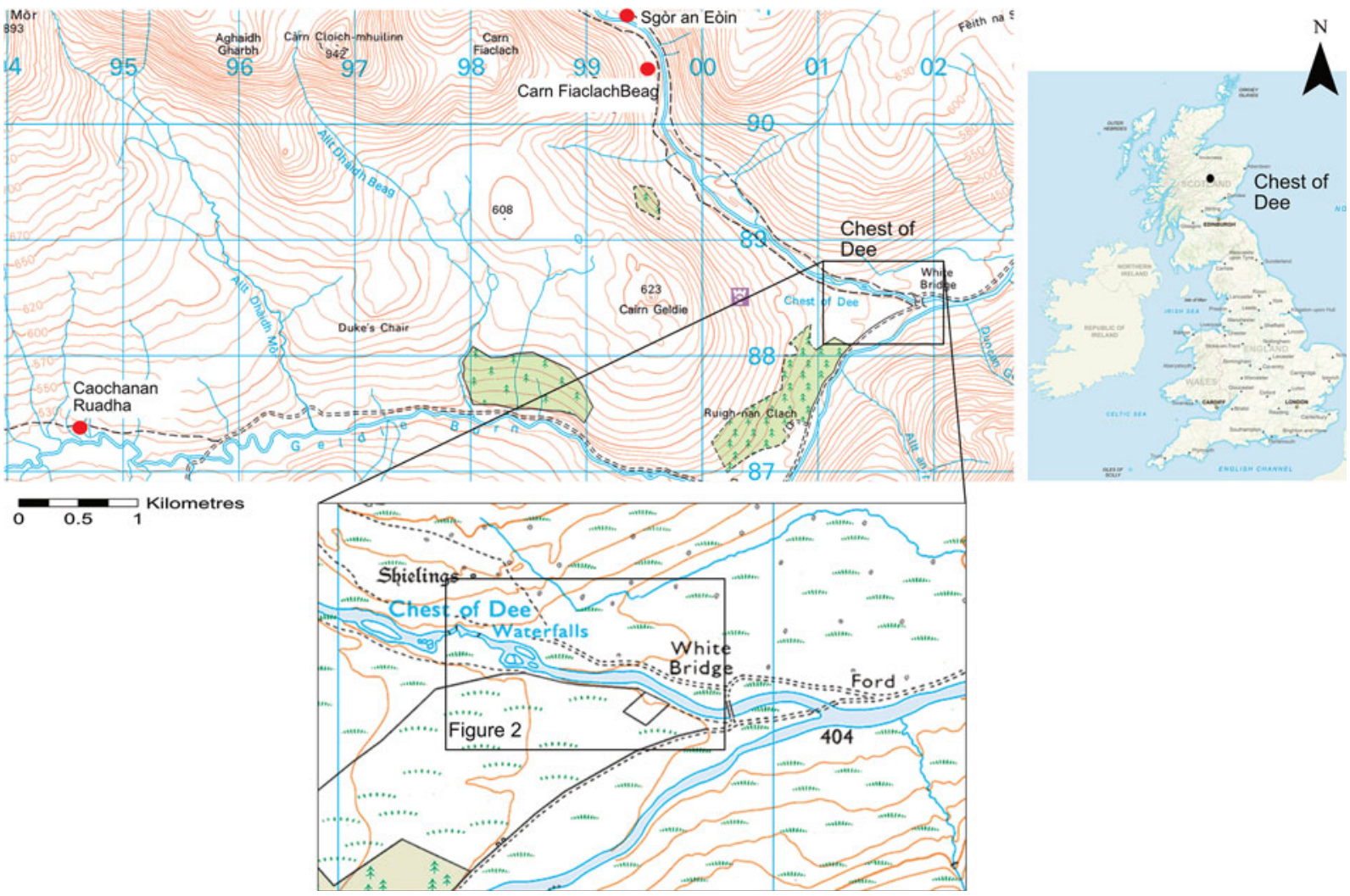

Fig. 1.

Chest of Dee: site location. Note the location of the Geldie Burn to the south-west of the River Dee (base map () Crown Copyright/database right 2020. An Ordnance Survey/EDINA supplied service)

and a significant contribution to the Scottish, and wider, Mesolithic. New approaches can be rewarding and the vulnerability of upland landscapes to predicted climate impacts adds significance to their archaeology.

We report on an interdisciplinary project in the eastern highlands of Scotland, the Upper Dee Tributaries Project (UDTP), where recently excavated evidence indicates long-term use of the Scottish uplands in the Mesolithic. New archaeological work in the Cairngorms has uncovered a range of sites occupying different locations across a wide upland landscape higher than $400 \mathrm{~m}$ above sea level (asl) and implying occupation from at least c. $8200 \mathrm{cal} \mathrm{BC}$ - close to the earliest dated Holocene inhabitation of eastern Scotland. The focus of this paper is the site of Chest of Dee, a stretch of early Holocene river terrace near the headwaters of the River Dee, lying between deeplycut waterfalls and a river confluence (Figs 1 \& 2). Occupation spreads and features such as fire-pits suggest extensive, intensive, and recurring activity in this upland landscape until the early 4 th millennium BC, with limited evidence for continued use in later prehistory.

\section{THE LANDSCAPE \& ENVIRONMENT OF THE CAIRNGORMS}

The Cairngorm Mountains comprise the largest continuous block of high ground in Britain, with several summits rising to $1200 \mathrm{~m}$ asl above gently moulded, high-altitude granite plateaux. Glaciated, U-shaped valleys dissect the plateaux and open to broad, dynamic, gravel-rich alluvial valley floors (Brazier et al. 1996) providing high connectivity through the mountains, including along the east-flowing River Dee and its westerly extension, the Geldie Burn (Figs $1 \& 2$ ). Today almost treeless (Fig. 3), with acid soil and blanket peat, pollen records within $5 \mathrm{~km}$ of the Chest of Dee describe dense Scots pine 


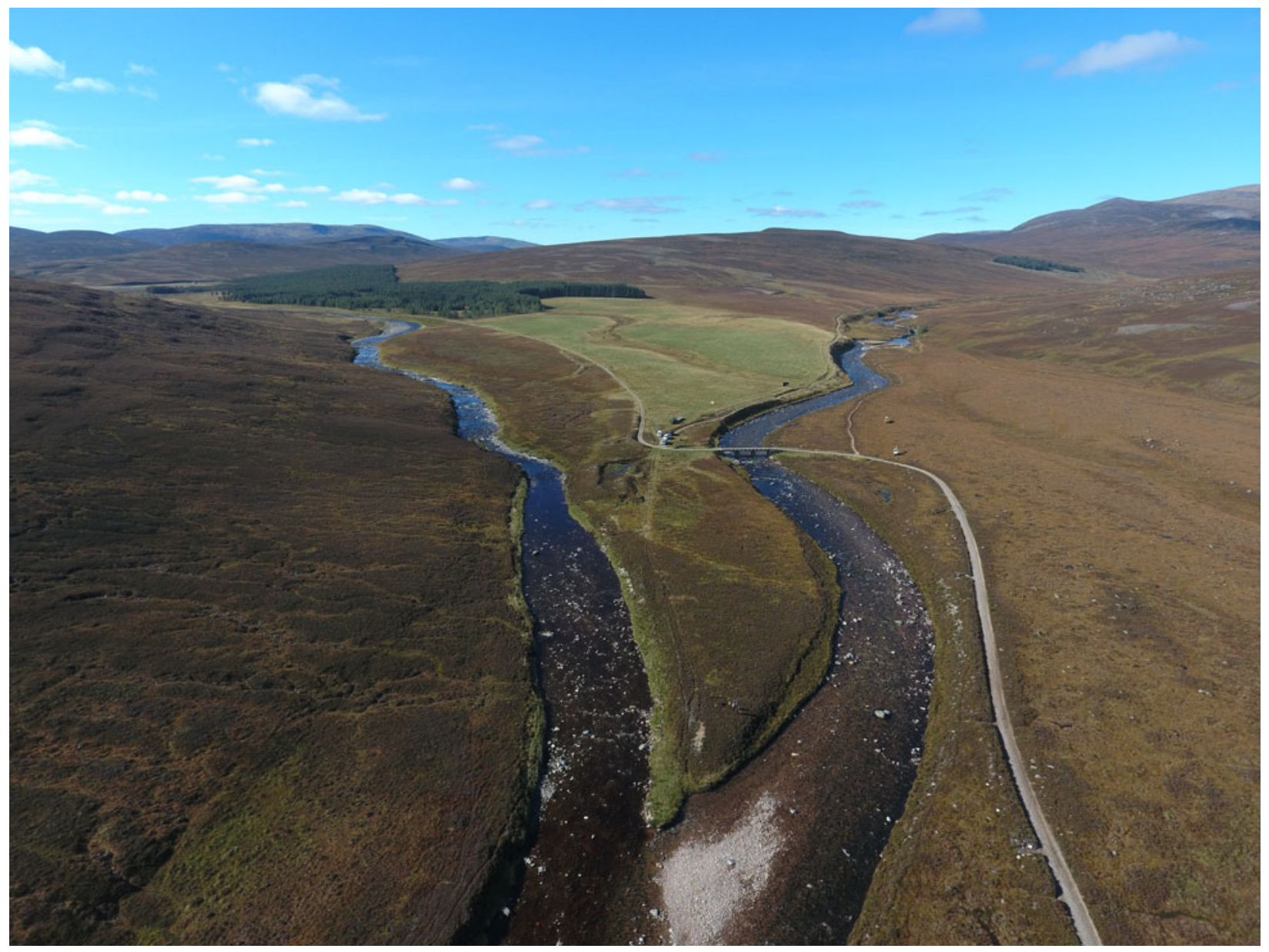

Fig. 2.

Chest of Dee, Aberdeenshire, from the east. White Bridge centre right, with the River Dee on the right and the Geldie Burn to the left

dominated forest displacing birch on valley floors after $c .7500 \mathrm{cal}$ BC. This gave way to more varied and open pine-birch woodland - much of it growing on blanket peat - which may have been disturbed with fire by people during the Mesolithic (Paterson 2011, 264). While areas of heather and grass existed at higher altitudes, all the archaeological sites discussed here were below the natural tree line (Bennett 1996).

The climate is harsh, and has been more so in the past (McClatchey 1996); north-facing corries held ice during the 'little ice age' of the early modern period (Kirkbride et al. 2014). During the most intense climatic deterioration in the Holocene, centred on c. 6200 cal BC (Alley \& Ágústdóttir 2005) the high Cairngorm may have supported comparable glacial conditions (Harrison et al. 2014).

\section{THE UPPER DEE TRIBUTARIES PROJECT:} METHODOLOGIES \& INITIAL FIELDWORK

Mesolithic occupation of the Cairngorm massif was unknown prior to 2003, when a programme of footpath repair revealed lithic scatters, some with Mesolithic characteristics, on the National Trust for Scotland's Mar Lodge Estate, comprising around 29,400 ha of land within the central Cairngorms. At the Chest of Dee, lithic artefacts were revealed by both footpath reconstruction and natural erosion along a $300 \mathrm{~m}$ stretch of riverbank. Subsequent survey in advance of further footpath repair identified a tightly-focused lithic scatter in disturbed ground on the opposite bank of the Dee $2.75 \mathrm{~km}$ upstream at Carn Fiaclach Beag (2006) while, about $7.5 \mathrm{~km}$ to the west in the upper reaches of Glen Geldie, a small number of lithics were recorded in 


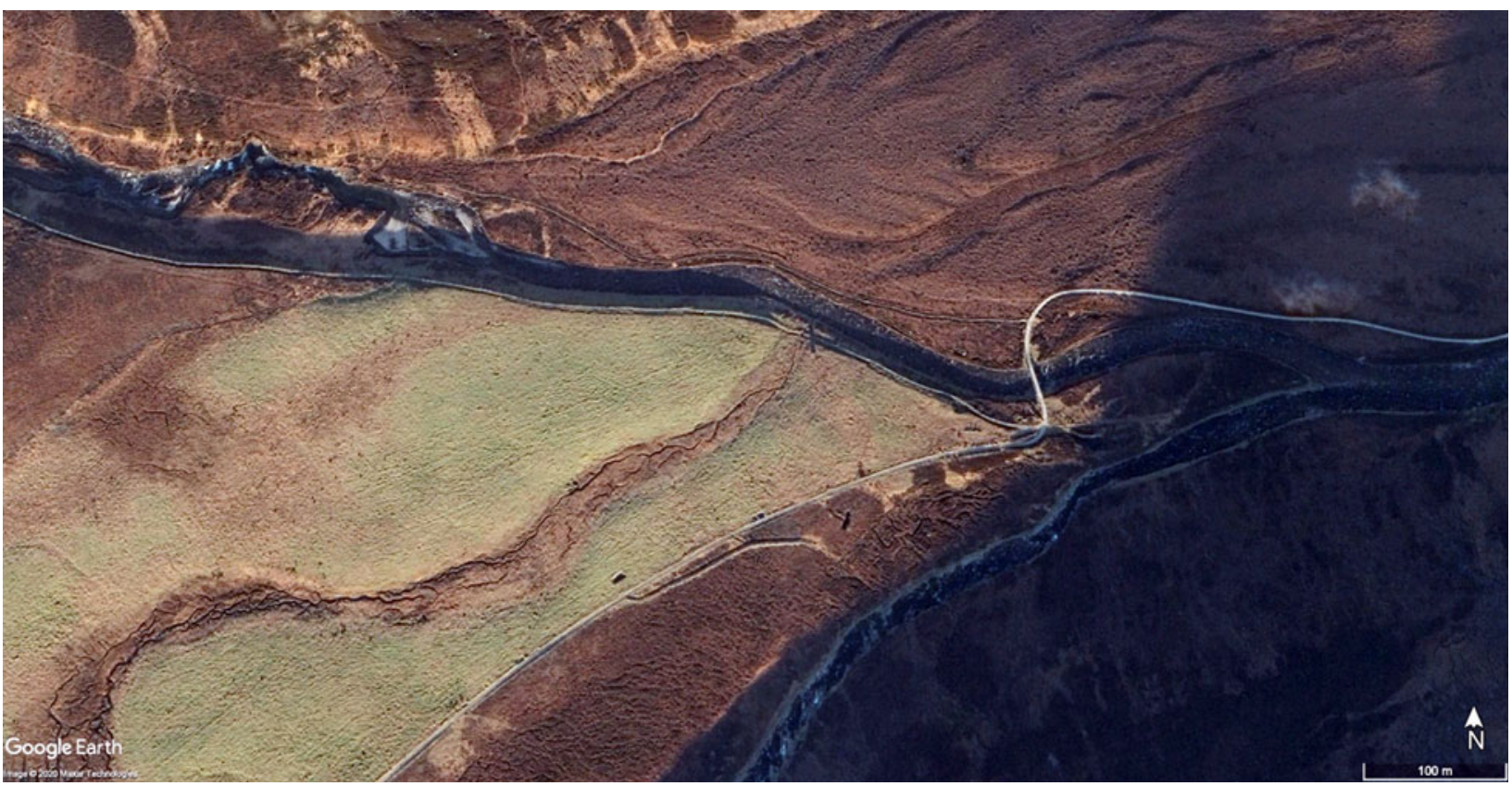

Fig. 3.

Chest of Dee: satellite shot of the confluence of the River Dee and the Geldie Burn at White Bridge. North is to the top. The archaeological site lies along the riverbank in the upper half of the photograph and the waterfalls and gorge may be seen towards the upper left (image: Google Earth. () 2020 Maxar Technologies)

a $4 \mathrm{~m}$ stretch of eroding footpath at Caochanan Ruadha (2005; Warren et al. 2018).

The UDTP was established by the National Trust for Scotland in 2012, in partnership with University College Dublin and the Universities of Aberdeen and Stirling, in the context of an extensive conservation programme of woodland expansion across the estate, including riparian planting. Given the lack of understanding of prehistoric inhabitation in these uplands, large-scale tree-planting has serious archaeological implications, particularly as it concentrates on precisely those landforms where prehistoric discoveries are emerging. The project aimed to investigate the nature, location, and sequence of prehistoric inhabitation in its environmental context, and to address the complex conservation management issues relating to the archaeological resource.

In areas targeted for planting, geomorphological mapping defined stable, pre-Holocene surfaces and thus areas of the highest potential for in situ preservation of archaeological remains. Nevertheless, extensive Holocene peat cover, albeit thin, meant that prospection was demanding. Erosion is one of the few processes by which sites are brought to archaeological attention, caused mainly by the use and repair of footpaths and by rivers and streams. However, these provide extremely limited windows of archaeological visibility across a vast landscape (Fraser et al. in press).

\section{EXCAVATION AT CHEST OF DEE}

The site at Chest of Dee lies at $415 \mathrm{~m}$ asl, just upstream of White Bridge where the Geldie Burn flows into the River Dee (Fig. 1). The lithic material occured along a footpath running next to the Dee, and was later identified to be eroding out of the riverbank materials. 'High-build' path reconstruction works involved cutting a strip of turves to either side of the proposed line of the path, then inverting them to create a raised routeway with drainage at the edges. This process brought the mineral soils lying directly beneath the peat onto the path surface; over subsequent years, the artefacts they contained gradually weathered out. Artefacts were collected over a number of visits by both amateur and professional archaeologists, producing an assemblage of 184 artefacts, mainly narrow blade technology, with a smaller assemblage of possible 


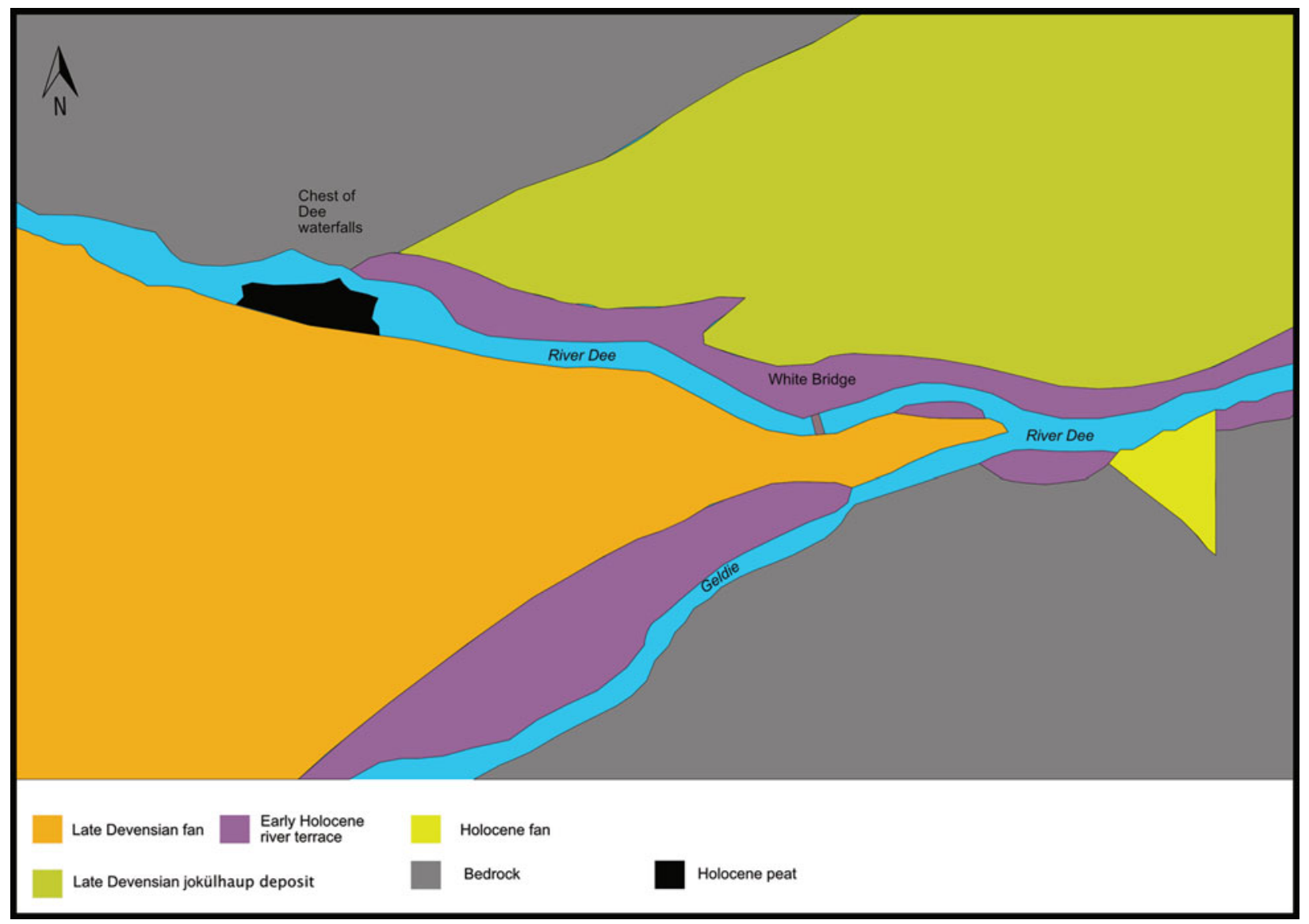

Fig. 4.

Schematic geomorphology at the Chest of Dee

Neolithic-Bronze Age material (Ballin, unpublished information; Clarke, unpublished information).

\section{Geomorphology and landscape}

The River Dee flows across bedrock to the Chest of Dee cataracts, created by an igneous dyke. To the south it is bordered by a well-drained Late Devensian alluvial fan seen in the mid-distance in Figure 2. At this point, it enters a deeply incised rock-cut gorge and falls $6 \mathrm{~m}$ over roughly $175 \mathrm{~m}$ distance (Figs $1 \& 3$ ). The gorge itself, formed in the Younger Dryas when the waterfall and surrounding valley floor were active as part of a wider meltwater channel, seems not to have seen a continuous history of water flow throughout the Holocene. At the head of the waterfalls, where the river swings north to enter the gorge, an earlier bedrock-lined channel, c. $50 \mathrm{~m}$ to the south, has been abandoned. This relict channel is likely to mark the main course of the river once fluvial discharge dropped at the end of the Younger Dryas. It is now filled with peat (Fig. 4), the basal deposit of which has been radiocarbon dated to 6610-6460 cal BC (SUERC-64468, $7697 \pm 37$ BP) (Table 1). The active channel probably switched back to the gorge through avulsion around this time. The resultant change in river dynamics served to reactivate the the waterfall and its downstream pools and protected the ephemeral archaeological deposits downstream of the cataracts as the focus of the river's energy was steered away from a direct impact on Area J (Fig. 5).

East of the waterfalls, the river has cut through Late Devensian and across Holocene fluvial deposits (Fig. 4). The highest and oldest of these surfaces is a large, deeply channelled spread of enormous boulders, probably deposited by a Younger Dryas-age glacial flood or jökulblaup, which would have filled the 
TABLE 1. CHEST OF DEE: RADIOCARBON DATES

\begin{tabular}{|c|c|c|c|c|c|c|}
\hline Lab. no. & Material & Context/sample & $\begin{array}{l}\text { Radiocarbon } \\
\quad \text { age }(B P)\end{array}$ & $\delta^{13} \mathrm{C}(\% \circ)$ & $\begin{array}{c}\text { Calibrated } \\
\text { range } \\
(95 \% \\
\text { confidence) } \\
\text { (cal BC) }\end{array}$ & $\begin{array}{c}\text { Calibrated } \\
\text { range } \\
(68 \% \\
\text { confidence) } \\
\text { (cal BC) }\end{array}$ \\
\hline SUERC-64468 & amorphous peat & $\begin{array}{l}\text { base of peat in palaeochannel, Chest } \\
\text { of Dee }\end{array}$ & $7697 \pm 37$ & -28.7 & $6604-6461$ & $6587-6480$ \\
\hline SUERC-64476 & young Betula sp. wood & $\begin{array}{l}\text { base of peat on valley floor of } \\
\text { Geldie Burn }\end{array}$ & $8870 \pm 37$ & -26.9 & $8223-7838$ & 8200-7959 \\
\hline SUERC-58528 & $\begin{array}{l}\text { charcoal: Betula sp. }(<20 \\
\text { rings) }\end{array}$ & $\begin{array}{l}\text { 2014. TP300; sample 010; charcoal } \\
\text { on old land surface at eroding } \\
\text { river edge } 10-12 \mathrm{~m} \text {, Area F }\end{array}$ & $8977 \pm 29$ & -25.2 & $8290-7990$ & $8270-8210$ \\
\hline SUERC-75306 & charcoal: Betula sp. & $\begin{array}{l}2016 \text { TP5250; context 5261; sample } \\
\text { 201; fire-pit S side of river }\end{array}$ & $8598 \pm 34$ & -28.8 & $7710-7560$ & $7630-7570$ \\
\hline SUERC-74125 & charcoal: Betula sp. & $\begin{array}{l}\text { 2016. TP5250; context 5261; } \\
\text { sample 201; fire-pit south side of } \\
\text { river }\end{array}$ & $8497 \pm 31$ & -26.9 & $7590-7520$ & $7580-7540$ \\
\hline SUERC-58527 & $\begin{array}{l}\text { charcoal: Salix sp }(<20 \\
\text { rings })\end{array}$ & $\begin{array}{l}\text { 2014. TP200; context 001; sample } \\
\text { 004; fire-pit at eroding river edge } \\
\text { 2-3 m, Area F }\end{array}$ & $7990 \pm 28$ & -26.2 & $7050-6770$ & $7040-6830$ \\
\hline SUERC-65011 & charcoal: Pinus sylvestris & $\begin{array}{l}\text { 2015. TP200; context 212; sample } \\
\text { 1012; (hearth/occupation layer) }\end{array}$ & $7958 \pm 27$ & -26.9 & $7040-6700$ & $7030-6770$ \\
\hline SUERC-65015 & charcoal: Pinus sylvestris & $\begin{array}{l}\text { 2015. TP400; context 420; sample } \\
\text { 1017; in situ fire-pit }\end{array}$ & $7974 \pm 35$ & -26.3 & $7050-6700$ & $7030-6820$ \\
\hline SUERC-65016 & charcoal: Pinus sylvestris & $\begin{array}{l}\text { 2015. TP950; context 954; sample } \\
\text { 1074; charcoal-rich feature. Area } \\
\text { J }\end{array}$ & $7961 \pm 35$ & -26.4 & $7050-6700$ & $7030-6780$ \\
\hline SUERC-65013 & charcoal: Pinus sylvestris & $\begin{array}{l}\text { 2015. TP400; context 412; sample } \\
\text { 1016; in situ fire-pit }\end{array}$ & $7945 \pm 35$ & -25.8 & $7040-6690$ & $7030-6700$ \\
\hline SUERC-65017 & charcoal: Pinus sylvestris & $\begin{array}{l}\text { 2015. TP1000; context 1014; } \\
\text { sample 1019; charcoal-rich feature }\end{array}$ & $7941 \pm 35$ & -26.5 & $7040-6870$ & $6870-6690$ \\
\hline SUERC-58526 & $\begin{array}{l}\text { charcoal: Pinus sylvestris } \\
\text { type }(<20 \text { rings })\end{array}$ & $\begin{array}{l}\text { 2014. TP200. context } 001 \text {; sample } \\
004 \text {; fire-pit at eroding river edge } \\
2-3 \mathrm{~m} \text {, Area F }\end{array}$ & $7930 \pm 28$ & -25.5 & $7030-6680$ & $6990-6690$ \\
\hline SUERC-65012 & charcoal: Pinus sylvestris & $\begin{array}{l}\text { 2015. TP200; context 212; sample } \\
\text { 1012; hearth/occupation layer }\end{array}$ & $7912 \pm 35$ & -26.6 & $7030-6650$ & $6910-6680$ \\
\hline SUERC-65005 & charcoal: Salix sp. & $\begin{array}{l}\text { 2015. TP200; context 202; sample } \\
\text { 1004; hearth/occupation layer }\end{array}$ & $7904 \pm 35$ & -27.1 & $7030-6640$ & $6830-6670$ \\
\hline SUERC-65006 & charcoal: Pinus sylvestris & $\begin{array}{l}\text { 2015. TP200; context 207; sample } \\
\text { 1005; hearth/occupation layer }\end{array}$ & $7885 \pm 35$ & -27.0 & $7030-6640$ & $6780-6650$ \\
\hline SUERC-65014 & charcoal: Pinus sylvestris & $\begin{array}{l}\text { 2015. TP400; context 413; sample } \\
1010 \text { in situ fire-pit }\end{array}$ & $7879 \pm 35$ & -26.2 & $7010-6630$ & $6770-6650$ \\
\hline
\end{tabular}


TABLE 1. (Continued)

\begin{tabular}{|c|c|c|c|c|c|c|}
\hline Lab. no. & Material & Context/sample & $\begin{array}{l}\text { Radiocarbon } \\
\text { age (BP) }\end{array}$ & $\delta^{13} \mathrm{C}(\%$ o) & $\begin{array}{c}\text { Calibrated } \\
\text { range } \\
(95 \% \\
\text { confidence) } \\
\text { (cal BC) }\end{array}$ & $\begin{array}{c}\text { Calibrated } \\
\text { range } \\
(68 \% \\
\text { confidence) } \\
\text { (cal BC) }\end{array}$ \\
\hline SUERC-65007 & charcoal: Pinus sylvestris & $\begin{array}{l}\text { 2015. TP200; context 207; sample } \\
\text { 1005; hearth/occupation layer }\end{array}$ & $7705 \pm 35$ & -26.4 & $6610-6460$ & $6590-6490$ \\
\hline SUERC-58520 & $\begin{array}{l}\text { charcoal: Pinus sylvestris } \\
\text { type }(<20 \text { rings })\end{array}$ & $\begin{array}{l}\text { 2014. TP103; context 003; test-pit } \\
\text { Area } \mathrm{F}^{1}\end{array}$ & $7225 \pm 28$ & -25.3 & $6210-6020$ & $6110-6020$ \\
\hline SUERC-59012 & $\begin{array}{l}\text { charcoal: Pinus sylvestris } \\
\text { type }\end{array}$ & $\begin{array}{l}\text { 2014. TP102; context 005; test-pit } \\
\text { Area F; small pit cut into } 007\end{array}$ & $7134 \pm 29$ & -24.8 & $6070-5920$ & $6040-5980$ \\
\hline SUERC-74122 & charcoal: Pinus sylvestris & $\begin{array}{l}\text { 2016. TP1200; context 1204; } \\
\text { sample } 007\end{array}$ & $6492 \pm 28$ & -25.5 & $5520-5370$ & $5490-5380$ \\
\hline SUERC-50742 & $\begin{array}{l}\text { charcoal: Pinus sylvestris } \\
\text { type }\end{array}$ & $\begin{array}{l}\text { 2013. TP200; upper horizons; } 0.5 \mathrm{~m} \\
\text { test-pit Area F }\end{array}$ & $6249 \pm 28$ & -24.1 & $5310-5070$ & $5300-5210$ \\
\hline SUERC-58524 & $\begin{array}{l}\text { charcoal: Pinus sylvestris } \\
\text { type }(<20 \text { rings })\end{array}$ & $\begin{array}{l}\text { 2014. TP200; context } 023 \text {; sample } \\
\text { 105; fire-pit at eroding river edge } \\
\text { 4-5 m, Area F }\end{array}$ & $6236 \pm 29$ & -27.0 & $5310-5070$ & $5300-2000$ \\
\hline SUERC-58525 & $\begin{array}{l}\text { charcoal: Pinus sylvestris } \\
\text { type }(<20 \text { rings })\end{array}$ & $\begin{array}{l}\text { 2014. TP200; context } 023 \text {; sample } \\
\text { 105; fire-pit at eroding river edge } \\
\text { 4-5 m, Area F }\end{array}$ & $6216 \pm 28$ & -27.4 & $5300-5060$ & $5230-5070$ \\
\hline SUERC-50741 & $\begin{array}{l}\text { charcoal: Pinus sylvestris } \\
\text { type }\end{array}$ & $\begin{array}{l}\text { 2013. TP200; upper soil horizons; } \\
0.5 \text { m test-pit Area F }\end{array}$ & $6169 \pm 29$ & -25.2 & $5220-5030$ & $5210-5060$ \\
\hline SUERC-74121 & charcoal: Pinus sylvestris sp. & $\begin{array}{l}\text { 2016. TP1150; context } 1151 \text {; } \\
\text { sample } 1150\end{array}$ & $6104 \pm 28$ & -25.2 & $5210-4930$ & $5200-4980$ \\
\hline SUERC-28264 & $\begin{array}{l}\text { charcoal: Pinus sylvestris } \\
\text { type ( }<20 \text { rings })\end{array}$ & $\begin{array}{l}\text { 2014; TP111; context } 020 \text {; pit B } \\
\text { Area D } \text { D }^{2}\end{array}$ & $5074 \pm 28$ & -24.9 & $3960-3800$ & $3950-3800$ \\
\hline SUERC-50744 & $\begin{array}{l}\text { charcoal: Pinus sylvestris } \\
\text { type }\end{array}$ & $\begin{array}{l}\text { 2013. TP 111; context 002; pit B } \\
\text { Area D }\end{array}$ & $5074 \pm 27$ & -25.9 & $3960-3790$ & $3950-3800$ \\
\hline SUERC-50743 & $\begin{array}{l}\text { charcoal: Pinus sylvestris } \\
\text { type }\end{array}$ & $\begin{array}{l}\text { 2013; TP111; context 002; pit B } \\
\text { Area D }\end{array}$ & $5047 \pm 26$ & -25.0 & $3950-3780$ & $3940-3790$ \\
\hline SUERC-50746 & $\begin{array}{l}\text { charcoal: Pinus sylvestris } \\
\text { type }\end{array}$ & $\begin{array}{l}\text { lower fill of pit in area overlooking } \\
\text { waterfall (Area G) }\end{array}$ & $4155 \pm 29$ & -25.4 & $2880-2630$ & $2870-2680$ \\
\hline SUERC-50745 & $\begin{array}{l}\text { charcoal: Pinus sylvestris } \\
\text { type }\end{array}$ & $\begin{array}{l}\text { upper fill of pit in area overlooking } \\
\text { waterfall (Area G) }\end{array}$ & $3309 \pm 29$ & -26.4 & $1660-1510$ & $1620-1530$ \\
\hline
\end{tabular}




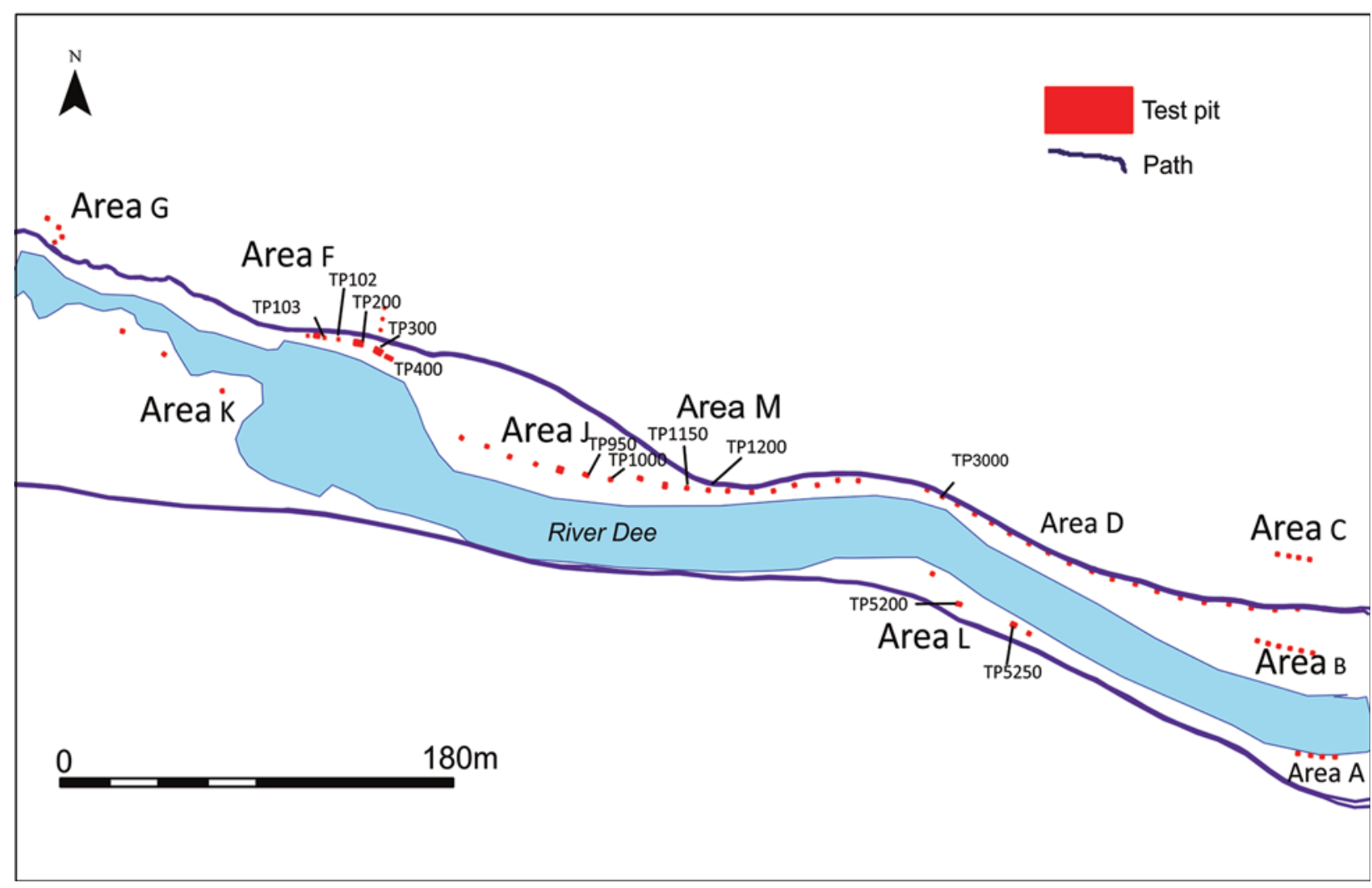

Fig. 5.

Chest of Dee: the test-pit locations

valley. It is now preserved on the north bank, for $2 \mathrm{~km}$ eastwards from the Chest of Dee. A lower terrace (Fig. 4: Early Holocene river terrace) incised c. $2.5 \mathrm{~m}$ lower than the surface of the jökulhlaup deposit, is visible in the meander scar left by an earlier channel where it eroded the jökulhlaup deposit. It is underlain by coarse glaciofluvial gravel. Initial aggradation of this terrace is not dated directly at White Bridge but a comparably early fluvial terrace fill has been dated in the Geldie Burn, west of White Bridge, to before $8230-7930 \mathrm{cal}$ BC (SUERC-64476, $8870 \pm 37 \mathrm{BP}$ ). The fill of the Chest of Dee terrace is a remarkably fine-grained silt (Fig. 7) which contrasts with the gravel-rich fluvial deposits formed here in the later Holocene. The origins of this silt remain uncertain. It is described here as a river terrace (Fig. 4), and it could reflect deposition by the River Dee in a wellwooded, geomorphologically quiescent period; nevertheless, it could also represent a lacustrine deposit ponded behind the jökulhlaup deposit. The majority of the archaeological material occurs on this terrace where the archaeological deposits are interleaved with sandy flood sediments apparently representing episodic inundation (Figs 6-8). Above the silt lies a thin layer of peat, developed once the fluvial processes across the terrace surface became less active.

\section{Fieldwork}

Test-pitting in October 2013 confirmed that the lithics came from in situ deposits, stratified within the prepeat alluvial silt deposits that comprised the river terrace, and that there were stratified features, in some cases associated with these artefacts. Subsequent work in 2014-2016 revealed a site of considerable complexity. The majority of test excavations in the evaluative stages were $0.5-2 \mathrm{~m}^{2}$, but larger trenches were also excavated across the focus of the densest lithic concentrations in one area (Area F). The excavation strategy in this large-scale landscape focused on identifying the presence/absence of lithics and stratified features. This enabled the evaluation of relative artefact densities 
C. Wickham-Jones et al. NEW EVIDENCE FOR UPLAND OCCUPATION IN THE MESOLITHIC OF SCOTLAND
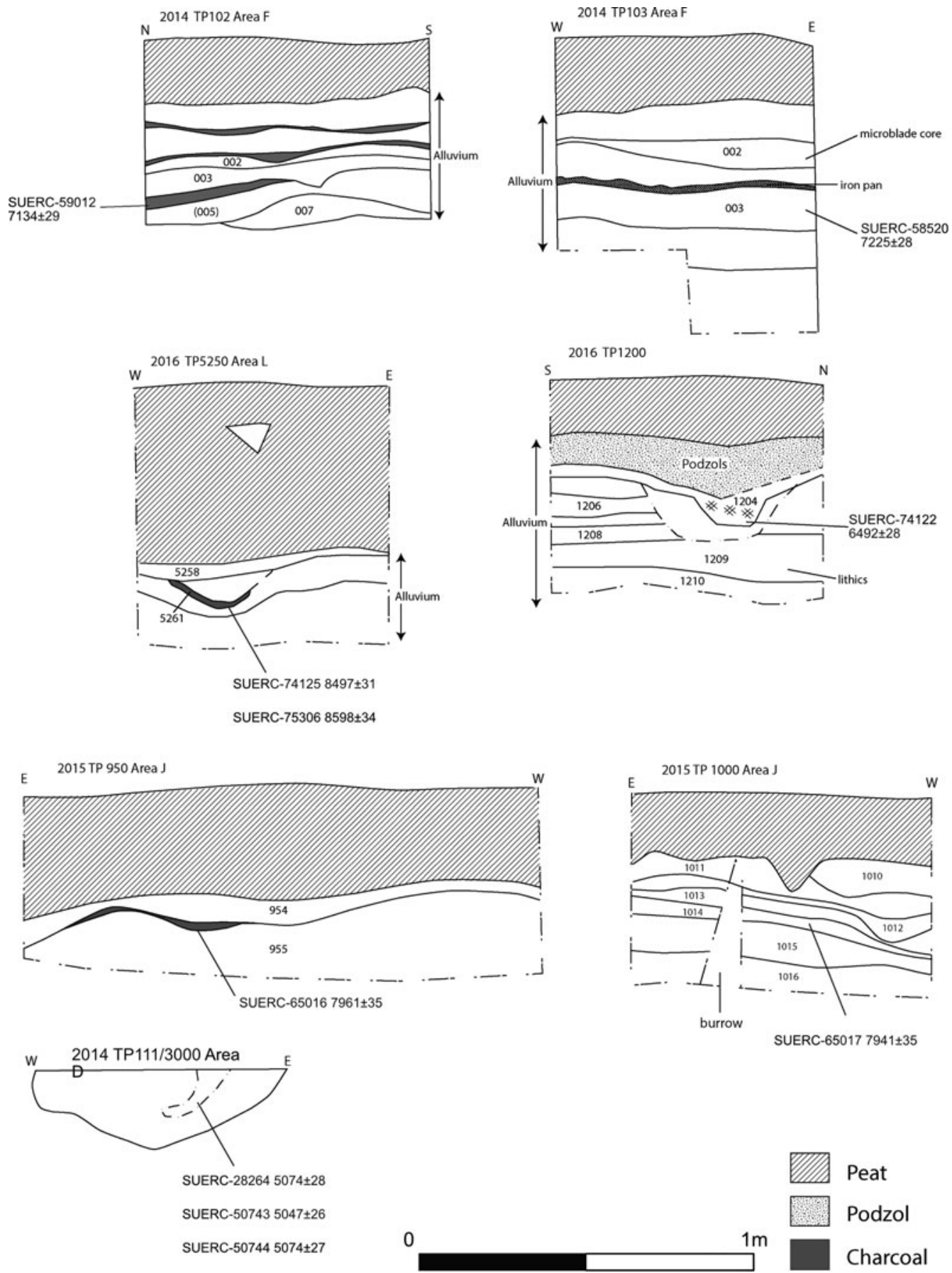

Fig. 6 .

Chest of Dee: example sections from the test-pits

and facilitated the placement of larger trenches. In addition, targeted test-pits were dug to provide characterisation of the soil/sediment stratigraphy. In this way, the utilisation of particular parts of the landscape could be mapped, and stratified material obtained for radiocarbon dating of the human activity. 


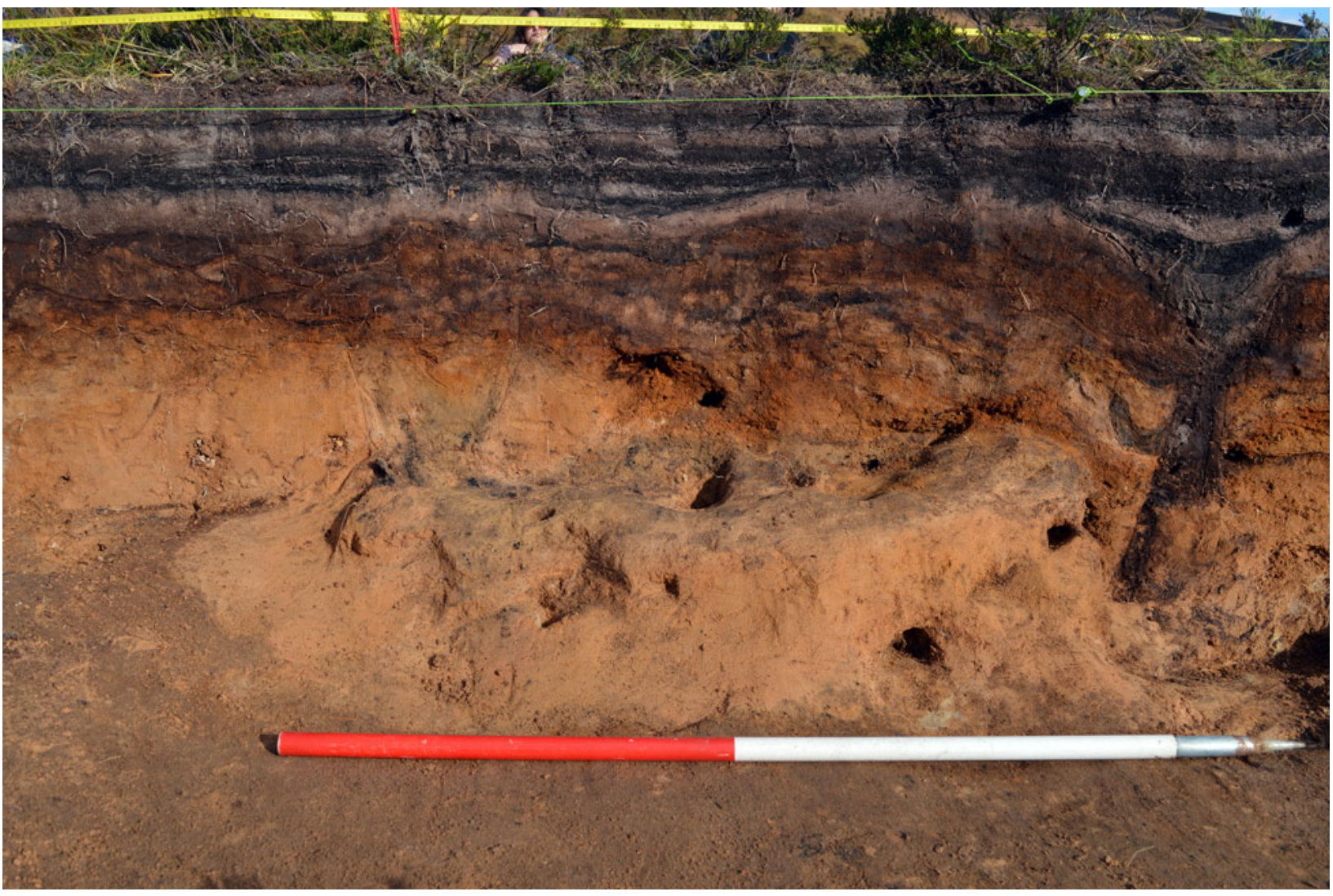

Fig. 7.

Chest of Dee: large pit (024) evidence in the eroding riverbank section. This was dated to the late 6th millennium cal BC. TP200 was laid out behind this feature

\section{EXCAVATION RESULTS}

The site was divided into evaluation areas (Fig. 5). Each area produced different lithic densities and, in addition, many of the test-pits revealed evidence of human activity in the form of spreads or lenses of charcoal and/or the presence of pits and occupation surfaces. Small quantities of birch and willow charcoal provided the earliest dates, while the majority of the charcoal from the features was of Scots pine type, consistent with the evidence for changing local woodland over the period (Paterson 2011).

Areas $B, C, D, J$, \& $M$

Some areas were relatively devoid of features or other indications of human activity. In Area B, for example, shallow peat deposits lay over undisturbed podzolised and alluvial soils. Further away from the river, Area C had a thin cover of peat and few features or finds: a single microlith, an isosceles triangle, was found in one of the test-pits, just below the peat.

The 19 test-pits in Area D contained larger concentrations of features and finds, including charcoal lenses within the pre-peat silts in some of them. Though there were few lithic artefacts in the test-pits at the eastern end of this area (see Table 2), artefact numbers increased towards the west. TP111 (expanded into TP3000, and henceforth referred to as TP3000) contained an assemblage of 72 lithics, including two flints, one a broad triangular microlith, within the charcoal-rich lower fill of a pit, c. $0.4 \mathrm{~m}$ diameter and $0.35 \mathrm{~m}$ deep (Figs 5, 6, \& 20). Samples from this fill produced date ranges of 3960-3780 cal BC (SUERC-28264, $5074 \pm 28 \mathrm{BP} ; \quad$ SUERC-50743, $5047 \pm 26 \mathrm{BP}$; and SUERC-50744, $5074 \pm 27 \mathrm{BP}$ ), placing this activity around the Mesolithic-Neolithic transition.

Area $M$ yielded slightly higher densities of lithics (up to 20 lithics in test-pits of $1 \times 1$ or $2 \times 2 \mathrm{~m}$ ). 
C. Wickham-Jones et al. NEW EVIDENCE FOR UPLAND OCCUPATION IN THE MESOLITHIC OF SCOTLAND

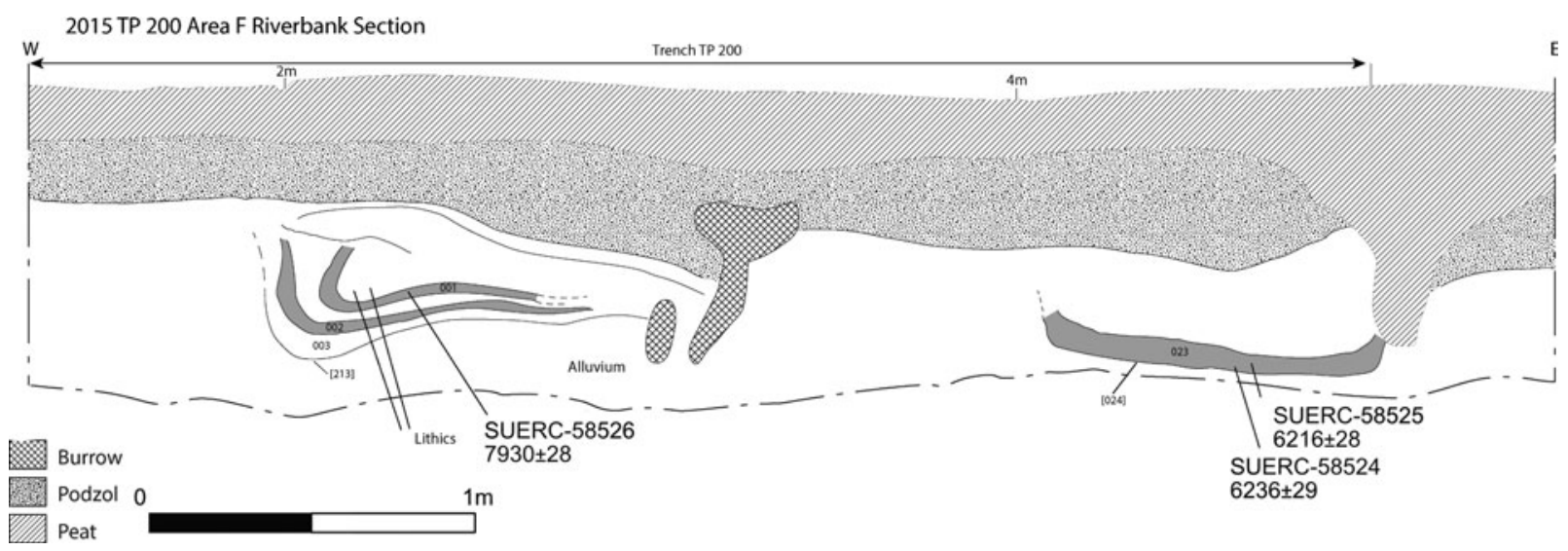

Fig. 8.

Chest of Dee: riverbank section next to TP200 showing features being eroded by the River Dee

In TP1150 this included a blade core from an occupation layer dated to $5210-4930 \mathrm{cal}$ BC (SUERC$74121,6104 \pm 28 \mathrm{BP})$. In TP1200, lithics were stratified in layers towards the base of the test-pit (Fig. 6). A terminus ante quem of 5520-5370 cal BC (SUERC$74122,6492 \pm 28 \mathrm{BP}$ ) was provided by charcoal from a small pit dug into the alluvium above these layers.

Test-pitting in other stretches in this area of the site did not produce lithic finds but some did yield evidence of human activity. In Area J, for example, pre-peat charcoal lenses and shallow pits occured in four test-pits. Charcoal from a shallow pit in TP 950 cut into the alluvial silts produced a date of 7050-6700 cal BC (SUERC-65016, $7961 \pm 35$ BP) (Fig. 6; Table 1). A lens of charcoal within TP1000 provided a similar date: $7040-6870 \mathrm{cal} \mathrm{BC}$ (SUERC-65017, $7941 \pm 35$ BP) (Fig. 6).

\section{Areas $A$ and $L$}

On the south side of the river, deeper deposits of peat up to $0.4 \mathrm{~m}$ deep were found in Area A, overlying large granitic boulders from the glacial outwash of the Devensian fan. Artefacts and other evidence of human activity were scarce in this area, only found in two of the four test-pits excavated in Area L. A spread of charcoal around $0.5-0.6 \mathrm{~m}$ in diameter and $0.04-0.05 \mathrm{~m}$ deep was recorded in TP5200, and a small pit, cut into the alluvial silts, was evident in the section of TP5250 (Fig. 6). Two small flint flakes were found at the same level as this pit, charcoal from which was dated to 7590-7520 and 7710-7560 cal BC (SUERC-75306, $8598 \pm 34$ BP; SUERC-74125, $8497 \pm 31$ BP) (Table 1).

\section{Area $F$}

The densest concentrations of lithics and features lay in Area F, just east of the gorge. Initial survey in 2013 identified some 50 artefacts on the current riverbank, in an area of active erosion. These included blade cores, flakes, and blades, together with possible occupation horizons evident in the eroding section (Figs $7 \& 8$ ). Nine test-pits and four larger trenches were excavated here, all with similar stratigraphy: around $0.3-0.4 \mathrm{~m}$ of peat development overlying podzolised and alluvial silt deposits up to $c .1 \mathrm{~m}$ in depth. Later consolidation of the surface is represented by the podzols, sealed in turn by later peat development. As in other areas, the lithic artefacts occurred in the pre-peat deposits, within layers sealed by alluvial sediments, or cut into the alluvial deposits from near the top of the pre-peat sequence. Pre-peat charcoal lenses and occupation spreads were found in nearly all of the excavation trenches in this area.

The two largest trenches in Area F (TP200 and TP300) contained the highest concentrations of lithics. A total of 662 pieces was recorded, including a high number of blade cores. TP200 was placed over a number of cut features evident in the eroding river section (Figs 8 \& 9). A number of charcoal lenses lay within the alluvial silts. They were shallow - rarely more than 0.02-0.03 $\mathrm{m}$ deep - and are interpreted as representative of a series of in situ occupation events on the alluvial terrace, occurring in the late 6th millennium BC (SUERC-50741, 6169 \pm 29 BP; SUERC-50742, $6249 \pm 28 \mathrm{BP}$ ) (Table 1). Lower in the profile, further charcoal spreads (eg, 202, 207, 208, 212 and 213; Figs $9 \& 10)$ produced significant lithic assemblages, 
TABLE 2. CHEST OF DEE: LITHIC RAW MATERIALS BY TEST-PIT

\begin{tabular}{|c|c|c|c|c|c|}
\hline Area & Test-pit & Flint & Rbyolite & $\begin{array}{l}\text { Other } \\
\text { stone }\end{array}$ & $\begin{array}{l}\text { Total } \\
\text { flaked } \\
\text { lithics }\end{array}$ \\
\hline $\mathrm{C}$ & $\mathrm{C} 4$ & 1 & 0 & 0 & 1 \\
\hline $\mathrm{D}$ & D8 & 1 & 0 & 0 & 1 \\
\hline $\mathrm{D}$ & D10 & 1 & 1 & 0 & 2 \\
\hline $\mathrm{D}$ & D17 & 2 & 0 & 0 & 2 \\
\hline $\mathrm{D}$ & D18 & 5 & 0 & 0 & 5 \\
\hline $\mathrm{F}$ & $\mathrm{F} 1$ & 4 & 0 & 0 & 4 \\
\hline $\mathrm{F}$ & $\mathrm{F} 2$ & 2 & 0 & 0 & 2 \\
\hline $\mathrm{F}$ & F3 & 1 & 0 & 0 & 1 \\
\hline $\mathrm{F}$ & TP101 & 1 & 0 & 0 & 1 \\
\hline $\mathrm{F}$ & TP102 & 6 & 0 & 0 & 6 \\
\hline $\mathrm{F}$ & TP103 & 3 & 0 & 0 & 3 \\
\hline $\mathrm{F}$ & TP106 & 60 & 56 & 1 & 117 \\
\hline $\mathrm{F}$ & TP109 & 1 & 0 & 0 & 1 \\
\hline $\mathrm{F}$ & TP150 & 3 & 0 & 0 & 3 \\
\hline $\mathrm{F}$ & TP200 & 131 & 446 & 10 & 587 \\
\hline $\mathrm{F}$ & TP300 & 73 & 1 & 1 & 75 \\
\hline $\mathrm{F}$ & TP400 & 20 & 0 & 0 & 20 \\
\hline M & TP1100 & 12 & 0 & 1 & 13 \\
\hline M & TP1150 & 1 & 0 & 0 & 1 \\
\hline M & TP1200 & 9 & 0 & 0 & 9 \\
\hline $\mathrm{M}$ & TP1450 & 3 & 0 & 0 & 3 \\
\hline $\mathrm{L}$ & TP5250 & 2 & 0 & 0 & 2 \\
\hline $\mathrm{L}$ & TP5300 & 0 & 0 & 1 & 1 \\
\hline $\mathrm{D}$ & TP3000 & 70 & 4 & 0 & 74 \\
\hline $\mathrm{F}$ & Section F & 41 & 54 & 2 & 97 \\
\hline \multirow[t]{3}{*}{ PATH } & PATH & 349 & 7 & 14 & 370 \\
\hline & Unstratified & 4 & 0 & 0 & 4 \\
\hline & Total & 806 & 569 & 30 & 1405 \\
\hline
\end{tabular}

including working debris from in situ blade production, using rhyolite and some flint (Fig. 9). These contexts produced several radiocarbon dates, in a range extending from the very end of the 8th through to the first half of the 7th millennium BC (SUERC 65005-65007 and SUERC 65011-65012) (Table 1).

At the river's edge were two eroded pits (Fig. 8). Dates from pit 213 were comparable to those from the earlier occupation horizons within TP200: 7030-6680 and 7050-6770 cal BC (SUERC-58526, $7930 \pm 28$ BP; SUERC-58527, $7990 \pm 28$ BP) (Table 1). A lower, charcoal-rich fill from the second pit, 024 , produced dates in the late 6 th millennium $\mathrm{BC}$ (5300-5060 cal BC: SUERC-58525, 6216 $\pm 28 \mathrm{BP}$; 5310-5070 cal вC: SUERC-58524, $6236 \pm 29$ вр).

TP300 was placed to investigate an area where an occupation surface was evident in the eroding river bank around $6 \mathrm{~m}$ east of TP200, towards the top of the alluvial deposits (Figs $11 \& 12$ ). Few artefacts or features were found in the trench until excavation neared the level of the occupation surface evident in section. Charcoal from this occupation surface produced a date of 8290-7990 cal BC (SUERC-58528, $8977 \pm 29$ BP) (Fig. 11; Table 1). At this depth lithics were found in the northern half of the trench, their distribution at the other side of the trench from the charcoal spread. Four small cut features associated with this surface were recorded, but none contained significant quantities of lithics or datable material (Fig. 12).

TP400 was placed $2.6 \mathrm{~m}$ from TP300, parallel to the river bank and adjacent to another charcoal horizon, $2 \mathrm{~m}$ in length and up to $0.08 \mathrm{~m}$ thick, situated near the top of the alluvial sand deposits in the eroding section (Figs $12 \&$ 13). The charcoal layer sealed an in situ fire-pit (421) and two other unexcavated charcoal-rich features (410 \& 419) (Figs $12 \& 13)$. The fire-pit measured c. $0.9 \mathrm{~m}$ across by $0.5 \mathrm{~m}$ transversely and $0.12 \mathrm{~m}$ deep (Fig. 13). It contained a dense but shallow layer of fire-cracked river cobbles (412) within a matrix of charcoal-rich soil. Below the stones was a layer of redeposited, orangy-brown sand (413) which in turn sealed a dense layer of charcoal (420), suggesting that the firepit had been reused. All three layers contained significant quantities of Scots pine charcoal which produced date ranges in the late 8 th to earlier 7 th millennium $\mathrm{BC}$ (SUERC-65013, $7945 \pm 35$ BP; SUERC-65014, $7879 \pm$ 35 BP; SUERC-65015, $7974 \pm 35$ BP) (Table 1).

TP102, a $1 \times 1 \mathrm{~m}$ test-pit dug to the west of TP200, showed at least three occupation horizons within c. $0.4 \mathrm{~m}$ of alluvial sand (Fig. 6). The test-pit was not bottomed, but lithics were identified in the lowest identified layer (007), which was formed prior to 6070-5920 cal BC (SUERC-59012, $7134 \pm 29$ вP) (Table 1). Two further layers containing artefacts (002 \& 003) lay above the lens of charcoal (005) which produced this date. Further west again, TP103 contained two blade cores, both in association with layers within the lower alluvial sands (Fig. 6). Sealed below a layer of hard iron pan, charcoal from the lower lithic-bearing layer (003) was dated to 6210-6020 cal BC (SUERC-58520, $7225 \pm 28$ BP) (Table 1).

In Area G, overlooking the waterfalls, a large, recut pit was evident in an eroding section of sloping ground above the footpath. Excavation indicated that the fill comprised charcoal-rich soil with large stones. The lower fill was dated to $2880-2630 \mathrm{cal} \mathrm{BC}$ and the upper 1660-1510 cal BC (SUERC 50746, $4155 \pm 29 \mathrm{BP}$; SUERC-50745, $3309 \pm 29$ вр) (Table 1). While not Mesolithic in date, the pit demonstrates activity into later prehistory in this striking landscape. 
C. Wickham-Jones et al. NEW EVIDENCE FOR UPLAND OCCUPATION IN THE MESOLITHIC OF SCOTLAND

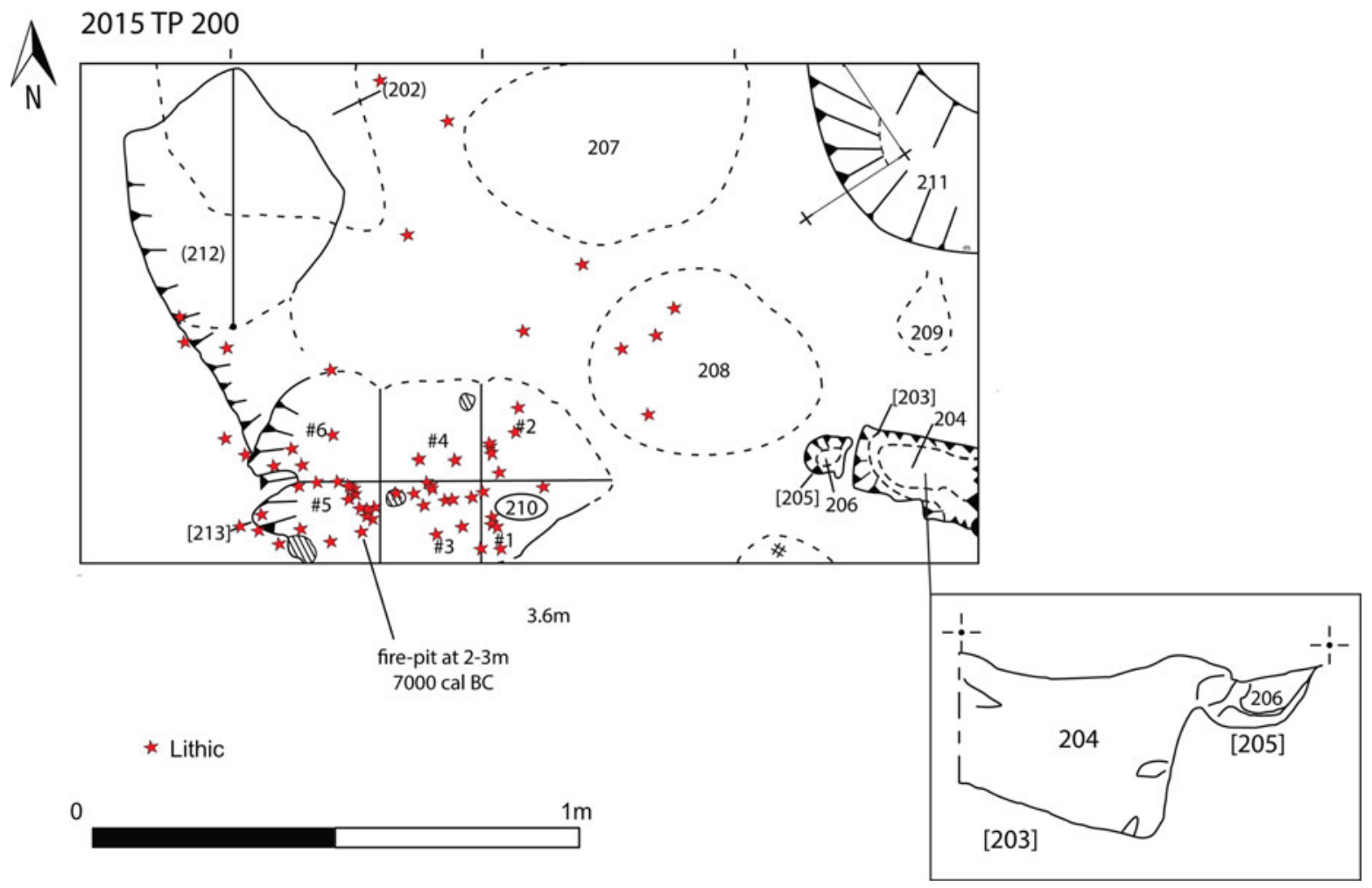

Fig. 9.

Chest of Dee: plan of lithic-bearing charcoal-rich spreads within TP200

\section{Lithics}

A total of 1405 flaked lithics was recovered from the investigations at Chest of Dee. A range of raw materials was flaked including flint $(57 \%)$, rhyolite $(41 \%)$, and a small proportion $(2 \%)$ of other materials comprising quartz, quartz crystal, quartzite, and sedimentary rock (Table 2). The rhyolite (Fig. 14) is of particular interest, as it has not previously been recognised in Mesolithic assemblages in Scotland. Identified as porphyritic flow banded rhyolite, the evidence from the flaked lithics suggests that it was sourced locally. Rhyolite-bearing intrusive dykes are common in the Cairngorms and the lack of any cortex or eroded surfaces, together with the size of the cores, indicates that this material was sourced from an outcrop. The nearest recorded rhyolite to the Chest of Dee lies in the valley of Allt an t-Sionnaich, which joins the Geldie Burn c. $1 \mathrm{~km}$ upstream of its junction with the Dee, and is mapped as having two intrusive dykes of 'microgranitic rocks' of Siluro-Devonian age intruded into psammites of the Grampian Group (Sheet $64 \mathrm{E}$ Ben Macdui 1:50,000 Scale Geology Series). Preliminary fieldwork did not identify knappable material in these mapped exposures, though the current peat cover makes identification of such outcrops difficult.

Flint was derived from pebbles, the potential sources of which have not yet been investigated. Although there are well-known deposits of gravel flint along the Buchan Ridge and also the Aberdeenshire coast to the east, the potential of the west coast of Scotland as a source for at least some of the flint at Chest of Dee should be considered. At the heart of the Cairngorm massif, Chest of Dee is well-placed for access from both west and east coasts as well as the Moray Firth.

The presence of cores, core trimming flakes and debitage of rhyolite and flint indicates that both materials were knapped on site (Fig. 15). Although the assemblage contains both flakes and blades (Table 3), the majority of cores were blade cores, made on both materials with flat platforms prepared to aid the 


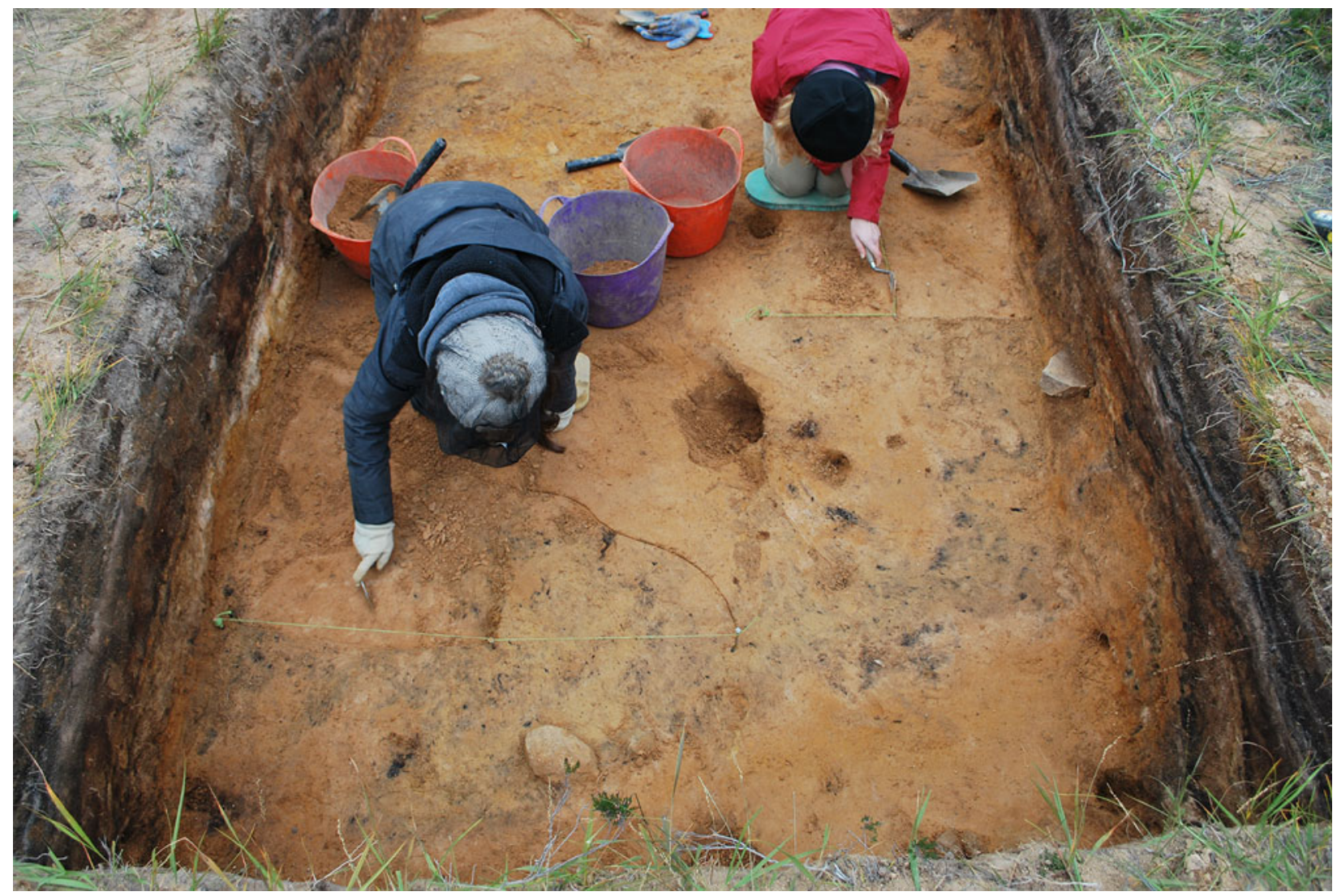

Fig. 10.

Chest of Dee TP200 during excavation from the west

2014 Riverbank Section Area F

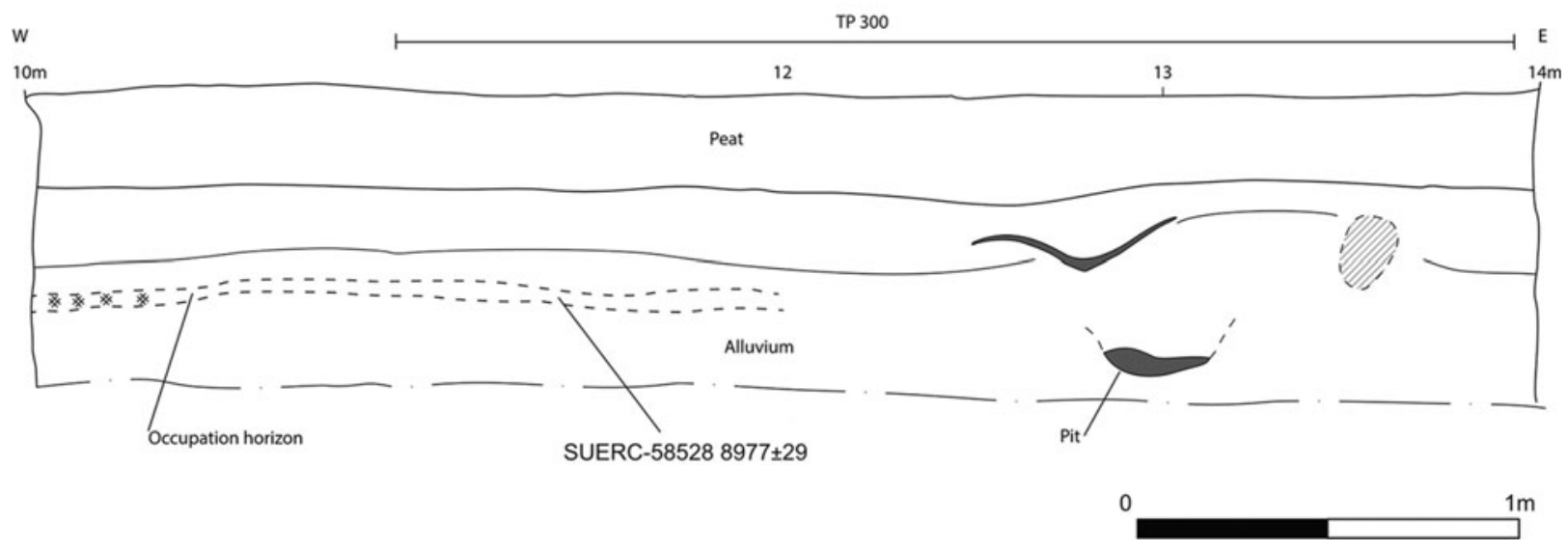

Fig. 11.

Chest of Dee: the riverbank section in Area F, to show the occupation horizon adjacent to TP300 
C. Wickham-Jones et al. NEW EVIDENCE FOR UPLAND OCCUPATION IN THE MESOLITHIC OF SCOTLAND

N

2015 TP 400 Area F

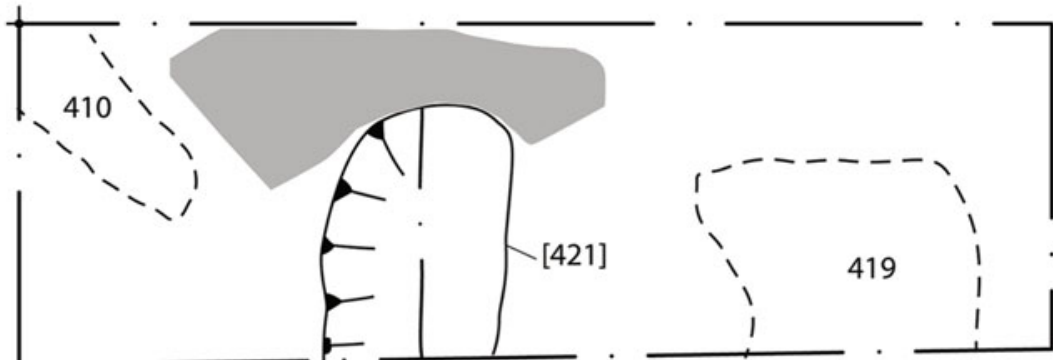

Heat-affected

sand

* Lithic

2015 TP 300 Area F

Charcoal

concentration

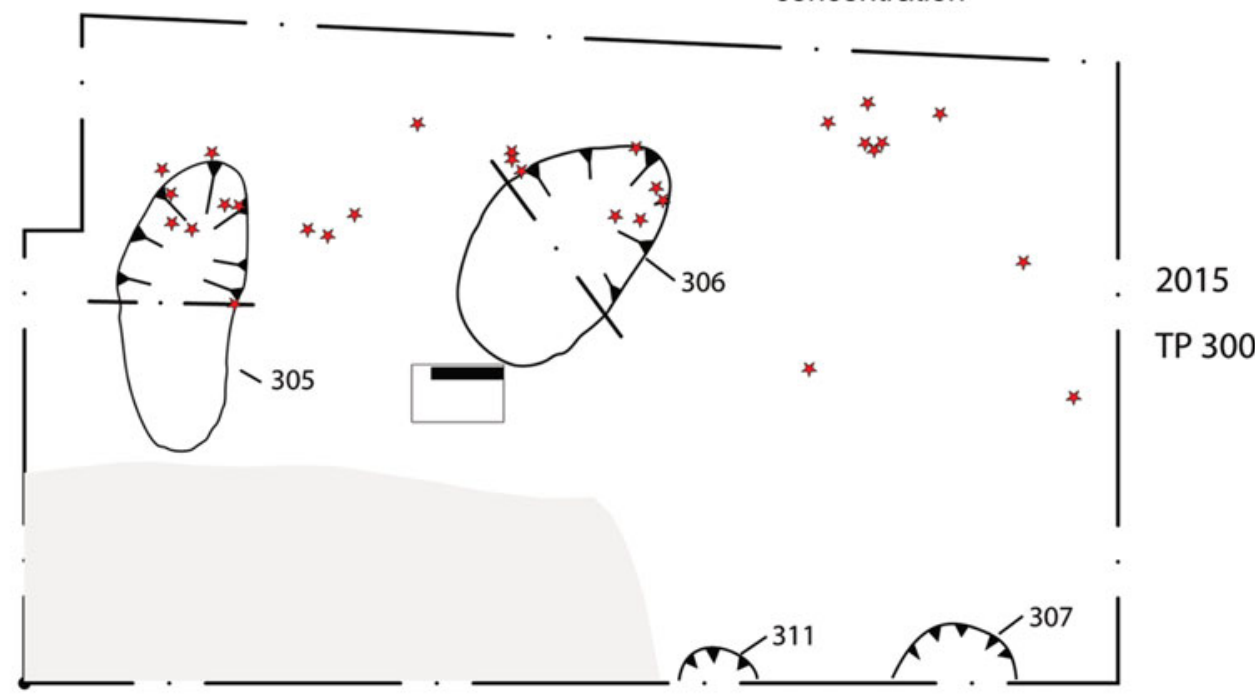

0

$2 m$

Fig. 12.

Chest of Dee: plan of TP300 and TP400

production of blades (Fig. 16). There is considerable variation in blade width $(3-26 \mathrm{~mm})$ with broader blades tending to be made of rhyolite (Figs $17 \& 18$ ). A small number of retouched pieces were identified, 42 in total, mainly on flint blanks $(n=39)$. Microliths of various forms, scrapers, awls and knife-forms were the most common tools with notched, serrated and edge retouched pieces also present (Table 4).

The largest number of lithics (587) came from TP200 in Area F (Table 2), this was the only location in which rhyolite was present in quantity and significantly outnumbered flint ( $80 \%$ of the assemblage). The large number of rhyolite cores $(n=15$; Fig. 19) and associated blades, flakes, and small flakes attest to the knapping of rhyolite here (Table 5). This is supported by the presence of two refitting flakes from the charcoal spread 212 which indicate that working took place close by, if not in situ. This rhyolite working focused on the production of unretouched blades (Fig. 18). There was little evidence of the selection 


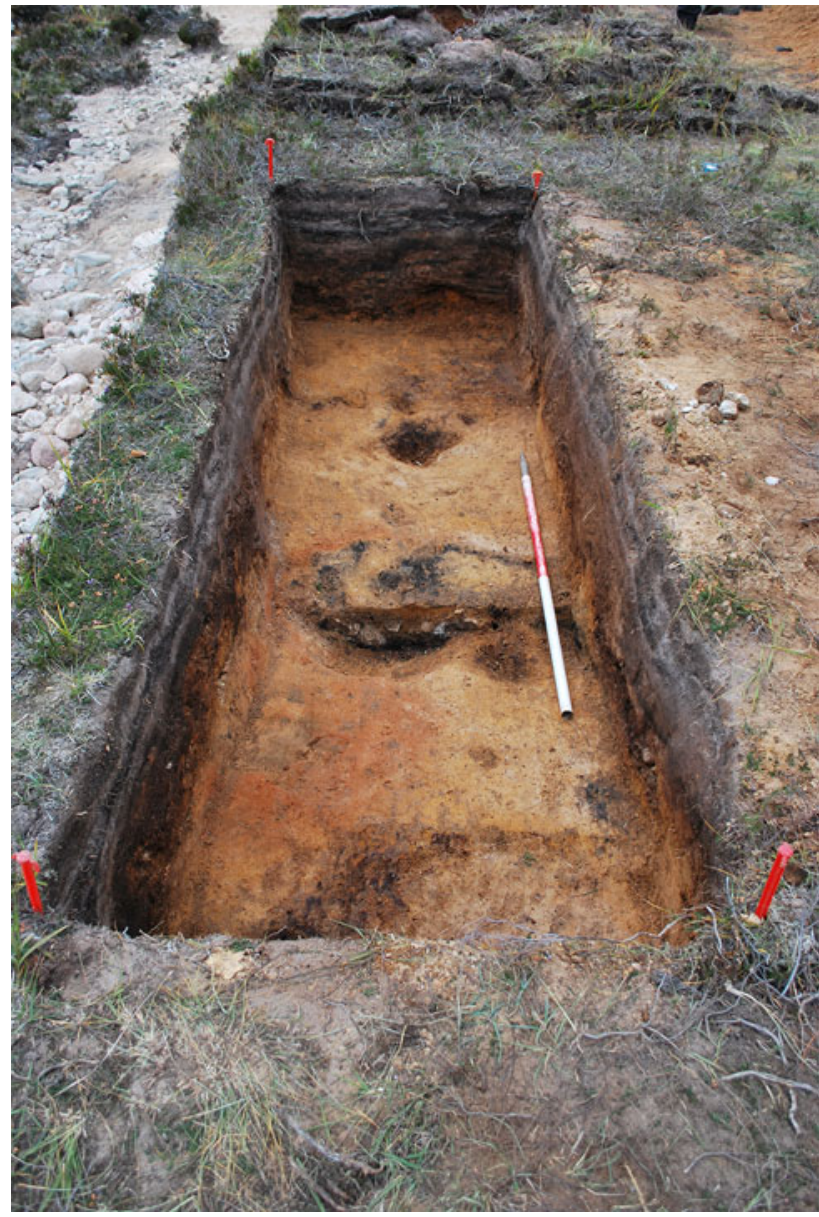

Fig. 13.

Chest of Dee: fire-pit (421) in the centre of TP400 from the east

of rhyolite blanks for further modification apart from one blade that had been used as a blank for an edgeretouched tool.

TP3000 produced another interesting lithic assemblage comprising 68 pieces of flint and four of rhyolite (Table 2). Flakes dominated over blades and there were only two retouched pieces, an awl, and a microlith. An interesting feature of this assemblage was the broad triangular microlith contained within a later pit (Fig. 20). Broad blade microliths such as this are commonly understood to represent some of the earliest Mesolithic industries in England, perhaps falling out of use by the early 8th millennium BC (Jacobi 1976; Saville 2004; Conneller et al. 2016), but they are not, to date, frequent finds in Scotland and where they do occur their chronological context is often uncertain. Although the archaeology at Chest of Dee does include

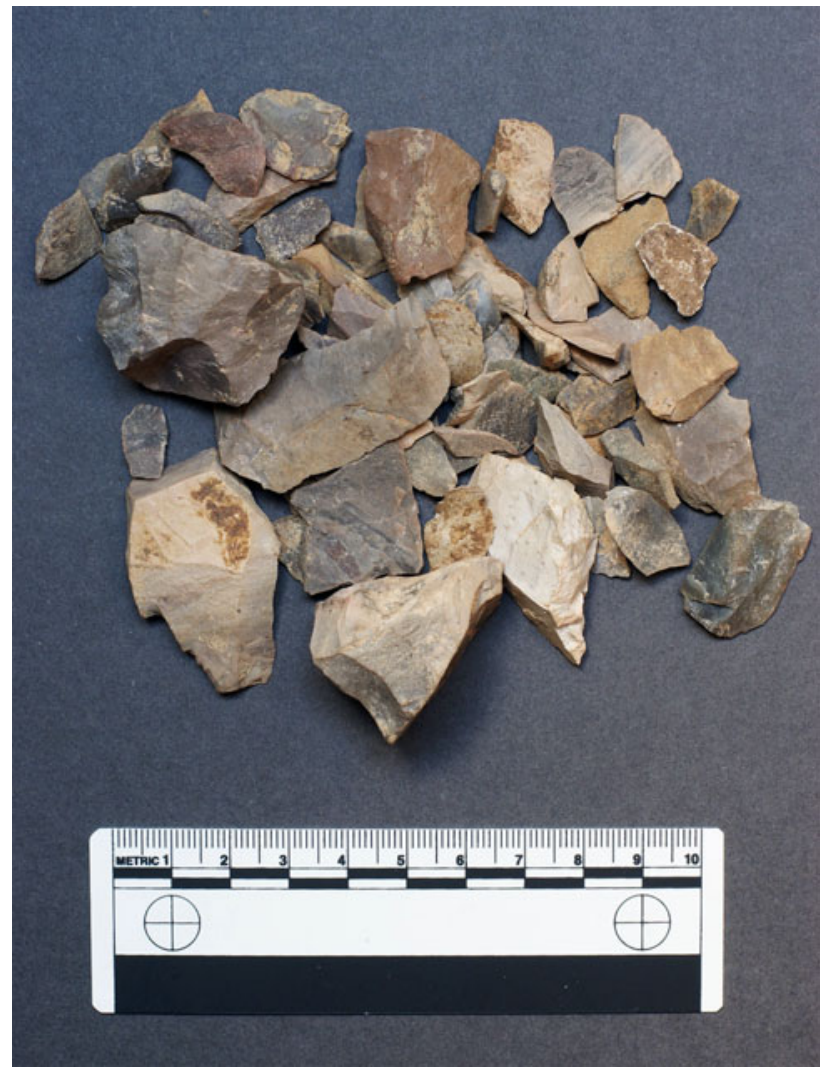

Fig. 14.

Chest of Dee: a sample of flaked rhyolite from TP100

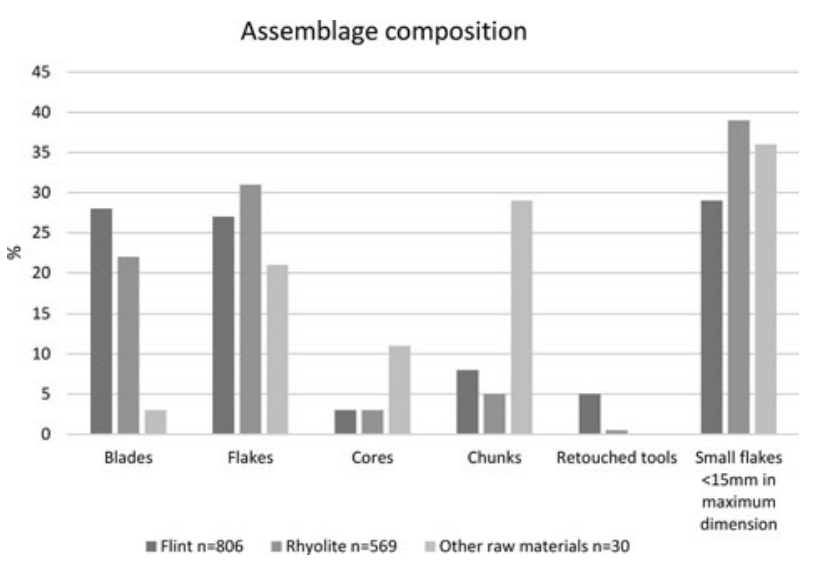

Fig. 15 .

Chest of Dee: breakdown of the raw materials by knapping product 
C. Wickham-Jones et al. NEW EVIDENCE FOR UPLAND OCCUPATION IN THE MESOLITHIC OF SCOTLAND

TABLE 3. CHEST OF DEE: LITHIC ASSEMBLAGE, ARTEFACT TYPES BY RAW MATERIAL

\begin{tabular}{|c|c|c|c|c|c|c|c|}
\hline Material & Blades & Flakes & Cores & Chunks & $\begin{array}{l}\text { Retouched } \\
\text { tools }\end{array}$ & $\begin{array}{c}\text { Small flakes } \\
<15 \mathrm{~mm} \\
\text { max. } \\
\text { dimension }\end{array}$ & Total \\
\hline Flint & 223 & 219 & 23 & 66 & 39 & 236 & 806 \\
\hline Rhyolite & 125 & 175 & 18 & 27 & 3 & 221 & 569 \\
\hline $\begin{array}{l}\text { Other raw } \\
\text { materials }\end{array}$ & $\begin{array}{c}\text { quartz } \times 1 \\
\text { quartzite } \times 1\end{array}$ & $\begin{array}{c}\text { quartz } \times 4 \\
\text { quartzite } \times 1 \\
\text { sedimentary } \times 1\end{array}$ & vein quartz $\times 3$ & $\begin{array}{c}\text { quartz } \times 7 \\
\text { crystal } \times 1 \\
\text { quartzite } \times 1\end{array}$ & 0 & $\begin{array}{c}\text { smoky quartz } \\
\text { crystal } \times 5 \\
\text { quartz } \times 2 \\
\text { quartzite } \times 3\end{array}$ & 30 \\
\hline Total & 350 & 400 & 44 & 102 & 42 & 467 & 1405 \\
\hline
\end{tabular}

\section{Core types by raw material}

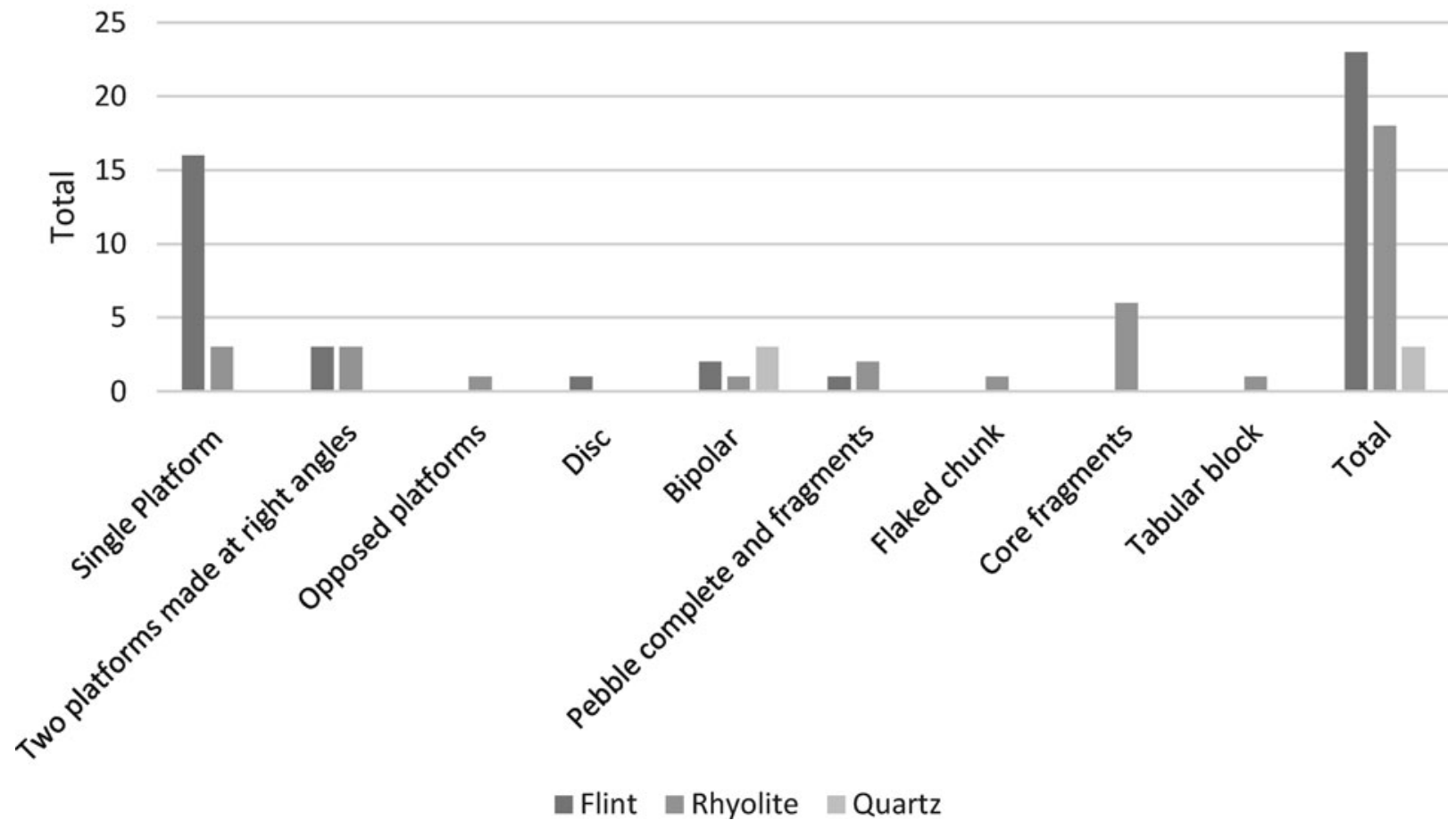

Fig. 16.

Chest of Dee: core types by raw material

dates indicative of activity at this early period, none of the three broad blade triangular microliths from the site is associated with the early deposits. This piece, from TP3000 is associated with a context dated to the Mesolithic-Neolithic transition, one comes from surface collection along the footpath, and one from the pre-peat ground surface in C4.

\section{Dating}

Multiple radiocarbon dates from Chest of Dee (Table 1) allow analysis and some Bayesian modelling of the determinations to be undertaken. The earliest dated feature is the occupation surface associated with lithics in TP300. The date of $8290-7990 \mathrm{cal} \mathrm{BC}$ (SUERC-58528) from charcoal in an occupation surface 


\section{Blade widths}

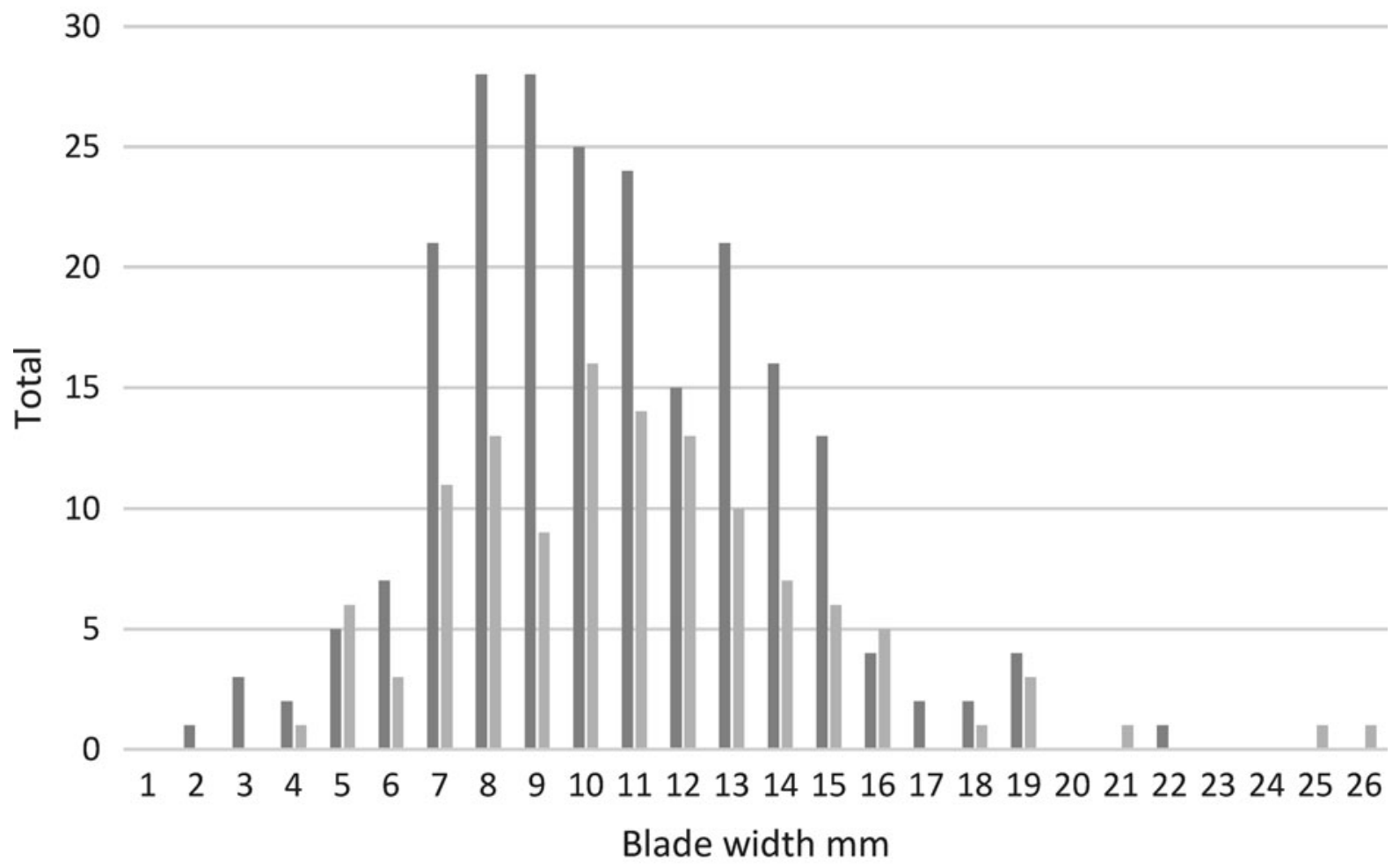

Flint $\quad$ Rhyolite

Fig. 17.

Chest of Dee: blade widths of flint and rhyolite

is amongst the earliest dates from a Mesolithic site in eastern Scotland. In TP5250, on the opposite side of the river, two results (SUERC-74125 and -75306) on charcoal recovered from a spread near a small pit and in association with two small flint flakes provide a slightly later date of 7590-7520 cal BC for activity (95\% probability; Fig. 21; last: TP5250).

These dates foreshadow the floruit of activity that occurred around the Chest of Dee in the first half of the 7th millennium cal $\mathrm{BC}$ that was picked up in TP200 and in Area J. The seven dates from TP200 (SUERC-58526, -65005-7, -65011-2, and -78527), the three from the fire-pit in TP400 (SUERC65013-5), and two dates from TP950 and TP1000 (SUERC-65016-7) suggest broadly contemporary activity along a short stretch of the north bank of the river. These 12 dates are not statistically consistent $\left(\mathrm{T}^{\prime}=52.4 ; \nu=11 ; \mathrm{T}^{\prime}(5 \%)=19.7\right.$; Ward \& Wilson
1978), suggesting some longevity to the deposition of dated material, however after removing SUERC65007 as a potential outlier the remaining results are statistically consistent $\left(T^{\prime}=12.2 ; v=10 ; T^{\prime}(5 \%)=\right.$ 18.3) and could all be the same actual age.

A chronological model was constructed with all of these dates in the computer program OxCal v.4.3 (Bronk Ramsey 2009) and following the structure of the simple bounded phase model presented in Hamilton and Kenny (2015). The model has good agreement (Amodel $=92$ ) and estimated this floruit of activity began in 7115-6810 cal BC (95\% probability; Fig. 22; start: 7 th millennium Chest of Dee), and probably in $7050-6885$ cal BC $(68 \%$ probability). This period of dated activity ended in 6645-6440 cal BC (95\% probability; Fig. 22; end: 7 th millennium Chest of Dee), and probably in 6630-6525 cal BC (68\% probability). An alternative model was constructed by excluding 


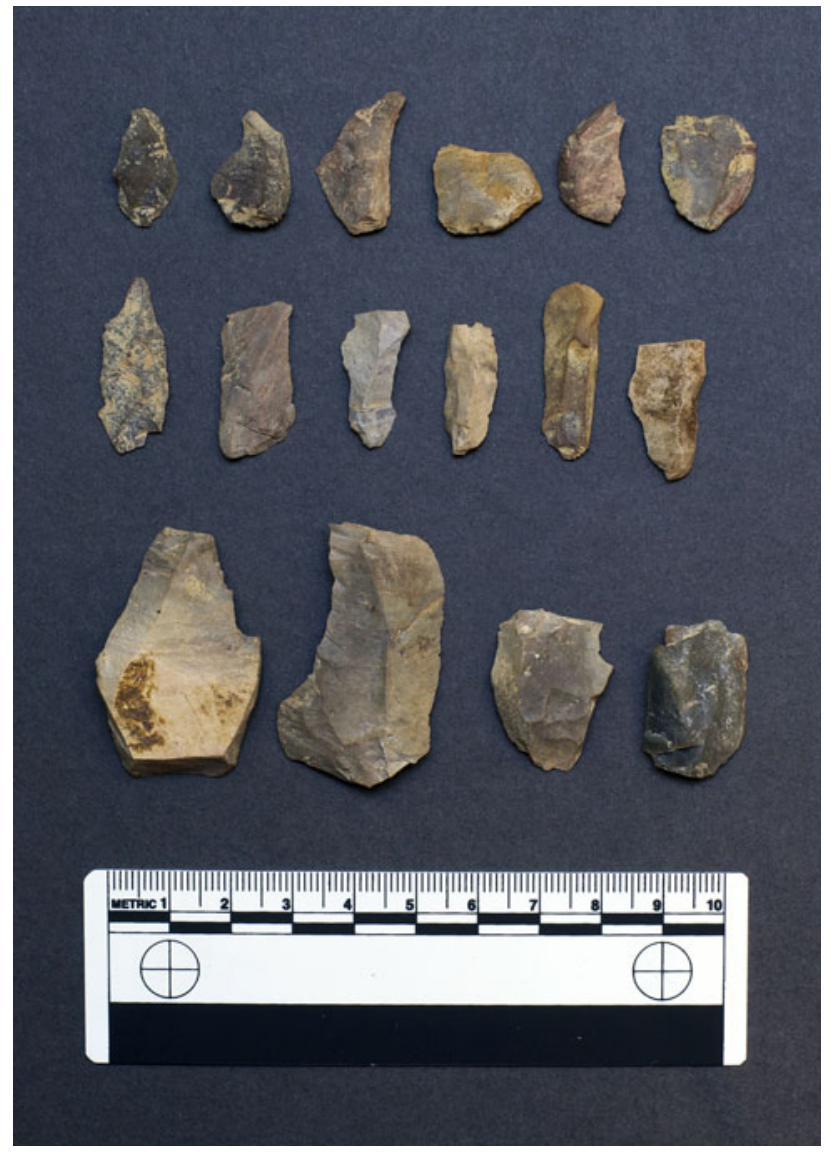

Fig. 18.

Chest of Dee: rhyolite blades and flakes

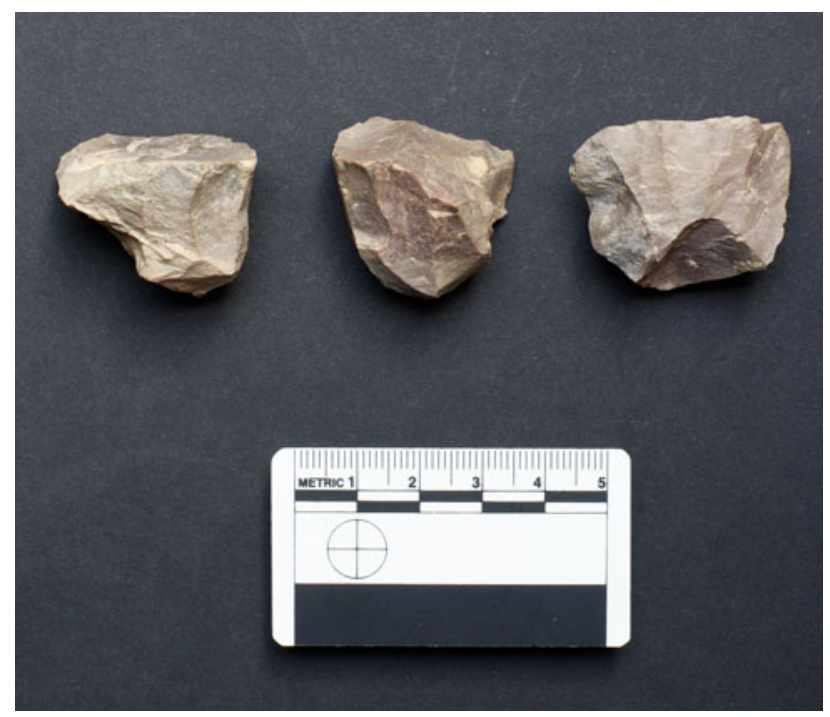

Fig. 19.

Chest of Dee: rhyolite cores

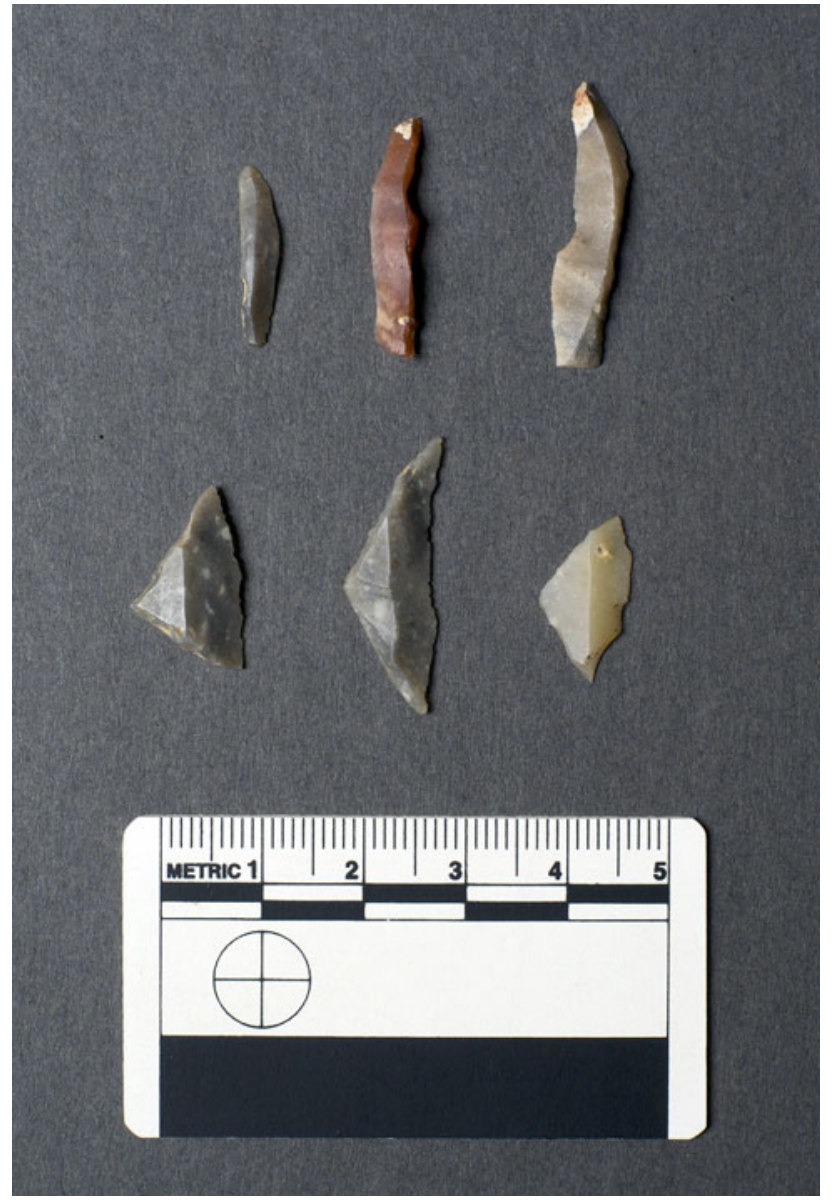

Fig. 20

Chest of Dee: microliths. Top row: Backed blades (1-r: F section; TP300; TP300); bottom row: Broad blade microliths (1-r: Path surface collection; TP3000; C4)

SUERC-65007 as an outlier. The alternative model also has good agreement (Amodel $=84$ ) and estimates this phase of activity on the Dee began in 7060-6765 cal BC (95\% probability; Fig. 23; start: 7 th millennium Chest of Dee (alt), and probably in 6925-6780 cal BC (68\% probability). This period of dated activity ended in either 6895-6880 $\mathrm{cal} \mathrm{BC}$ ( $1 \%$ probability; Fig. 23 ; end: 7 th millennium Chest of Dee (alt)) or 6825-6615 cal BC $(94 \%$ probability), and probably in 6795-6685 cal BC $(68 \%$ probability).

Occupation along this stretch of the bank in the late 7th-early 6th millennium cal $\mathrm{BC}$ is represented by the results from TP103 (6210-6020 cal BC; 95\% probability; Fig. 21; SUERC-58520) and TP102 (60705920 cal BC; 95\% probability; Fig. 23; SUERC-59012) 
TABLE 4. CHEST OF DEE: LITHIC ASSEMBLAGE, RETOUCHED PIECES BY TYPE AND CONTEXT

\begin{tabular}{|c|c|c|c|c|c|c|c|}
\hline$T P$ & Microlithic forms & Scrapers & $\begin{array}{l}\text { Edge } \\
\text { retouched }\end{array}$ & $A w l$ & Knife & $\begin{array}{c}\text { Serrated/ } \\
\text { denticulate }\end{array}$ & Notched \\
\hline TP106 & 0 & 0 & 1 (rhyolite) & 0 & 1 & 1 & 0 \\
\hline F Section & backed blade; microburin (rhyolite) & 0 & 0 & 1 & 0 & 0 & \\
\hline ТP200 & 0 & 1 & 3 (1 rhyolite) & 1 & 3 & 3 & 0 \\
\hline TP300 & $\begin{array}{l}\text { backed blade; backed blade; microlith } \\
\text { fragment; microburin }\end{array}$ & 1 & 0 & 0 & 0 & 0 & 0 \\
\hline TP1100 & 0 & 0 & 1 & 0 & 0 & 0 & 0 \\
\hline $\begin{array}{l}\text { TP3000 } \\
\text { (TP111) }\end{array}$ & broad triangle & 0 & 0 & 1 & 0 & 0 & 0 \\
\hline $\mathrm{C} 4$ & isosceles triangle & 0 & 0 & 0 & 0 & 0 & 0 \\
\hline D17 & obliquely blunted & 0 & 0 & 0 & 0 & 0 & 0 \\
\hline PATH & microburin; isosceles triangle; scalene triangle & 6 & 3 & 2 & 0 & 0 & 1 \\
\hline
\end{tabular}

All pieces are of flint except for three in brackets which are of rhyolite

TABLE 5. CHEST OF DEE: LITHIC ASSEMBLAGE, THE CONTENTS OF FEATURES IN TP200, RHYOLITE AND (FLINT)

\begin{tabular}{lcccccc}
\hline Feature & Blades & Flakes & Chunks & Cores & Retouched & Small flakes \\
\hline Fire-pit: Feature 210 + TP106 Ft 1 & $44(3)$ & $50(12)$ & $7(20)$ & 2 & $1(2)$ & $123(30)$ \\
Feature 212 & 0 & 5 & 0 & 0 & $0(1)$ & 0 \\
Feature 206 & 0 & 0 & 0 & 0 & 0 & 1 \\
\hline
\end{tabular}

and 6th millennium cal $\mathrm{BC}$ activity by results from TP1200 (5515-5375 cal BC; 95\% probability; Fig. 21; SUERC-74122), the upper horizons of TP200 (52205030 cal BC; 95\% BC; Fig. 21; last: TP200 Upper horizons) and TP1150 (5210-5000 cal BC; 95\% probability; Fig. 21; SUERC-74121).

Early 4th millennium cal BC activity is represented by the pit in TP3000. Three radiocarbon determinations are available from the fill of this pit (SUERC28264 and -50743/4), and the latest probability provides the best estimate for its infilling in 39153770 cal $B C$ (95\% probability; Fig. 21; last: Area D TP111), and probably in 3865-3790 cal BC $(68 \%$ probability). Finally, later prehistoric activity (3rd and 2 nd millennium $\mathrm{BC}$ ) was identified focusing on the waterfalls at the Chest of Dee, but also much further east, in Area D (1st millennium BC), disturbing features of the late 4th millennium BC (these later dates are listed in Table 1, but not considered further here).

\section{DISCUSSION}

\section{On-site archaeology}

The archaeology at the Chest of Dee suggests repeated visits to the Dee riverbank for over five millennia, starting in the late 9th millennium BC. Work has identified a particular concentration of activity in the early 7th millennium cal BC $(6795-6685 \mathrm{cal}$ BC, 68\% probability) based on model 2; Fig. 23). Lithic-bearing features end with a phase of activity in the early 4th millennium cal BC, in the period $3865-3790 \mathrm{cal} \mathrm{BC}$ (68\% probability).

This was a dynamic landscape. The Dee catchment generates major floods today (Maizels 1985; McEwen 2000) and would have done so in prehistory. The gorge and waterfall were inactive during much of the settlement history. Those who lived here prior to the mid-7th millennium $(6605-6460 \mathrm{cal}$ BC, 95\% probability; SUERC-64468; Table 1; base of peat in palaeochannel) experienced a landscape in which the main course of the river bypassed the waterfall. Only in the late 7th millennium cal BC did a shift of the river back into the gorge occur, probably as a result of avulsion. The terrace formation at the water's edge facilitated the creation of living space by Mesolithic communities through the Holocene, but it was not without inundation. The advantages of riverine and other resources outweighed the risks of episodic flooding.

The focus of human activity was on this terrace, directly west of the Dee and Geldie confluence. At this location people were able to take advantage of the many resources offered by the river, in an area of open woodland that lay well below the tree line 


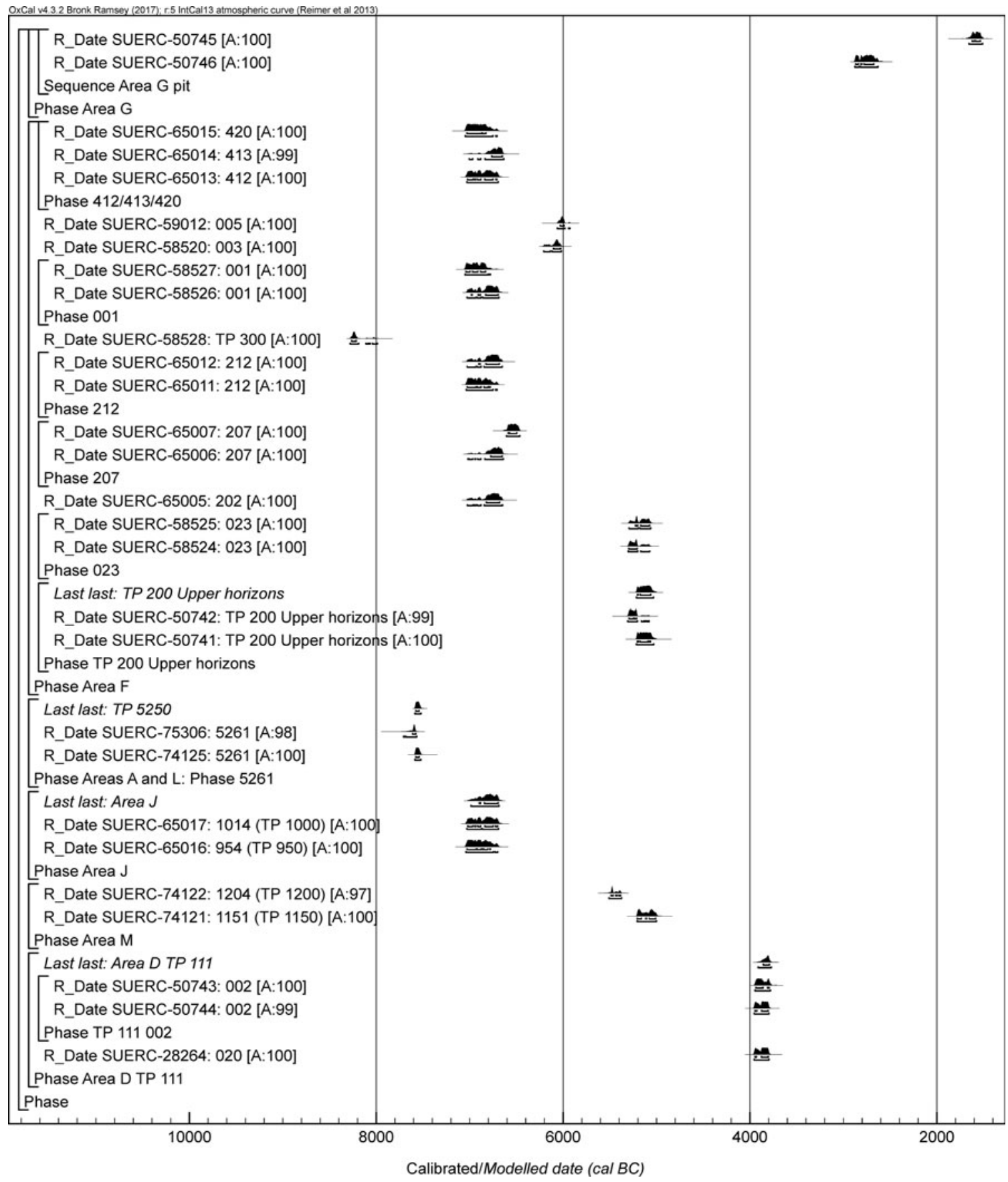

Fig. 21.

Chest of Dee: Oxcal V4.2 plot of the radiocarbon dates

(Pears 1968). Above the gorge on the Dee, walkover survey of the footpath and riverbanks for a distance of roughly $2 \mathrm{~km}$ has so far failed to identify any traces of occupation upstream, though without major erosion or test-pitting below the peat the presence/absence of archaeology here remains uncertain.

At the Chest of Dee, most of the archaeological evidence lies along the north bank of the river, in the 


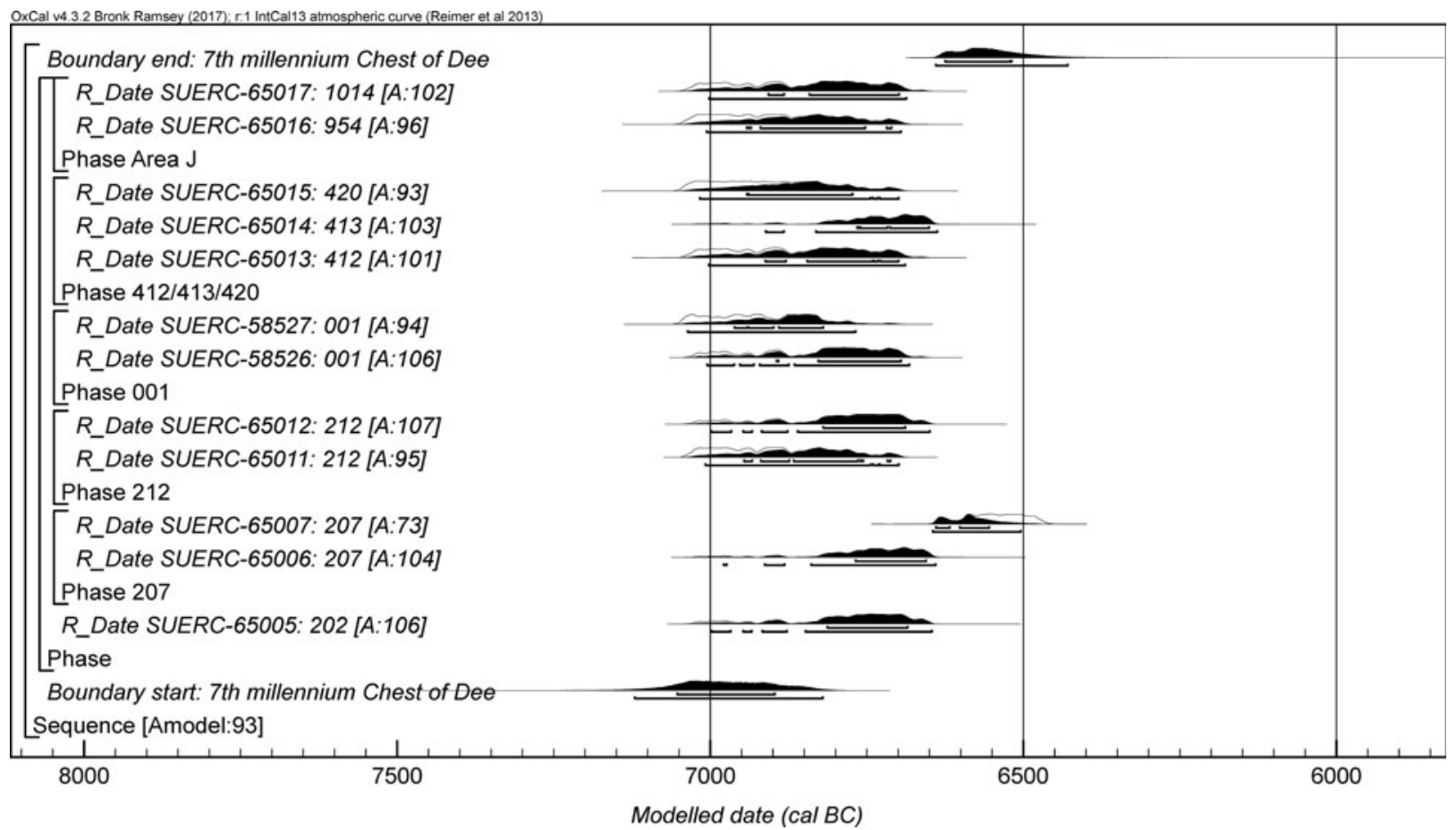

Fig. 22.

Chest of Dee: Model 1 of the 7th millennium cal BC activity

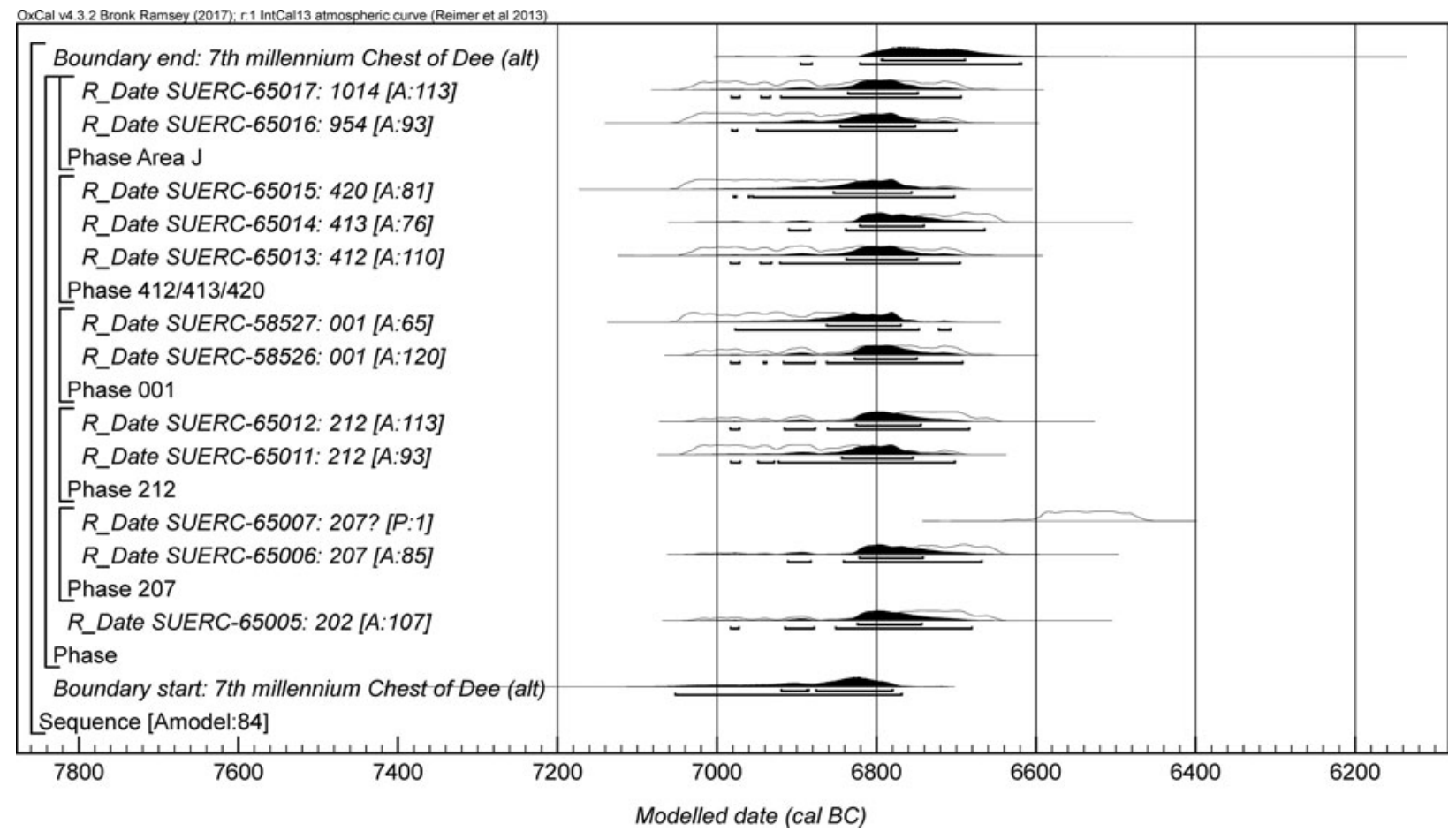

Fig. 23.

Chest of Dee Model 2 of the 7th millennium cal BC activity 


\section{Wickham-Jones et al. NEW EVIDENCE FOR UPLAND OCCUPATION IN THE MESOLITHIC OF SCOTLAND}

form of charcoal lenses and small pits with charcoal flecking which were found in the majority of the test-pits. The relative lack of similar material from the south bank of the river may perhaps be explained by the different conditions engendered by the absence of a comparable river-side terrace. While the lack of survival of organic material limits interpretation, the evidence suggests that Mesolithic activity included sourcing lithic materials from the Cairngorm uplands and further afield and working them to prepare blades and other tools, together with the lighting of fires for cooking and/or heat. From ethnographic and archaeological parallels, the fire-pit in TP400 may have been a cooking pit (Waselkov 1987, 100-5), though other interpretations are possible (Mithen 2019).

In TP200, the tight distribution of artefacts coinciding with charcoal-rich spreads and a pit, all within an area $2 \mathrm{~m}$ across, deserves comment. Dating and Bayesian modelling suggest these features and lithics were closely related chronologically and deposited around the same time as the activity evidenced in TP400 and in Area J, all in the period 7050-6885 cal $B C(68 \%$ probability) according to one model and $6795-6685$ cal BC (68\% probability) according to a second (occupation spreads and fire pit; Table 1; Figs $22 \&$ 23). The focus of lithic material in one area in TP200 is particularly intriguing and could be interpreted as marking the position of some sort of structure - perhaps a tent or light shelter (Fig. 9). If this is the case, the surviving evidence suggests that it was small, about the size of that at Caochanan Ruadha (Warren et al. 2018), though some material may have been lost to riverbank erosion.

Further work is necessary to establish the limits of the artefact and occupation spreads beyond the boundaries of the modest trenches and to fully characterise the site; to our knowledge few other Mesolithic sites in Britain or Ireland include stratified Mesolithic land surfaces where contemporary activity can be mapped across an extensive area. Later activity appears to have been more intermittent, but the extended radiocarbon chronology provides a strong indication that use of the Cairngorm uplands was not an occasional, random occurrence, but rather was fully integrated into Mesolithic lifeways from the earliest period of postglacial recolonisation.

\section{Inhabitation of the Upper Dee catchment}

Despite the geographic limitations of a small research project, it seems that early prehistoric inhabitation of the Cairngorms involved a complex range of activities, spread over a considerable geographical area, a system into which the site at Chest of Dee neatly fits. Upriver of Chest of Dee, at the Dee headwaters, small lithic scatters have been recovered at Sgòr an Eòin and Carn Fiaclach Beag - both chronologically undiagnostic (Fraser et al. in press). Further into the Cairngorms, some $8 \mathrm{~km}$ to the west, lies Caochanan Ruadha. Like Chest of Dee, this site provides good stratigraphic detail and well-contextualised lithics. Situated in an upland valley overlooking the Geldie Burn (c. $540 \mathrm{~m}$ asl), today it is remote and difficult to access. Excavations in 2013-15 uncovered a low-density scatter of worked flint covering an area of around $50 \times 25 \mathrm{~m}$, with outlying artefacts up to $380 \mathrm{~m}$ upstream (Warren et al. 2018). One concentration comprised around 100 lithics in a tight cluster within an area roughly $3 \times 2.2 \mathrm{~m}$, centred on a pit or hearth (Warren et al. 2018, figs $7 \& 8$ ). On the basis of lithic distribution this has been interpreted as a light shelter. Use-wear analysis, together with the general lithic technology, suggests that activities focused on the manufacture and maintenance of microlithic artefacts with the aim of obtaining and processing animal carcasses and plant materials. Dates show occupation of the shelter in the period $6220-6060 \mathrm{cal} \mathrm{BC}$ (95\% probability), probably contemporary with one phase of activity at Chest of Dee, eg, TP103 (62106020 cal BC; $95 \%$ probability; SUERC-58520). Further activity at Caochanan Ruadha, after some decades and possibly well over a century ( $8-164$ years; $95 \%$ probability; Warren et al. 2018, 939), is represented by a further small concentration of artefacts and associated charcoal spreads $c .50 \mathrm{~m}$ down-slope of this structure, once again broadly contemporary (Trench 5; 60806000 cal BC; $95 \%$ probability; R_Combine of SUERC67810 and -67814; Warren et al. 2018, 939), with activity at Chest of Dee (eg: TP102; 6070-5920 cal BC; 95\% probability; SUERC-59012).

While activity at Chest of Dee and Caochanan Ruadha may have overlapped in time, the sites are very different. There are notable differences between the lithic assemblages: in sharp contrast to the Chest of Dee assemblage, the artefacts from Caochanan Ruadha are dominated by narrow blade microliths, especially microlith fragments, microburins and snapped or fragmentary blades. Only flint was used and cores were absent, again in contrast to Chest of Dee. The extensive series of pits and charcoal spreads at Chest of Dee differs from the smaller site at Caochanan Ruadha, and Chest of Dee yielded a much 
greater number and density of lithics. Overall, the evidence suggests that while the Dee/Geldie confluence attracted intensive occupation, with repeated episodes of activity, Caochanan Ruadha, deeper into Glen Geldie, may only have been visited occasionally, perhaps for a night or two at a time (Warren et al. 2018, 944).

Chest of Dee was a location for repeated occupation, from which a range of more specialised activities elsewhere might be facilitated. Caochanan Ruadha may represent an example of precisely that sort of specialised site. The contrasting geographical locales make sense in this context: while Caochanan Ruadha overlooked a shallow upland glen containing peaty wetland and slow-flowing streams, occupation at Chest of Dee targeted the point in the landscape where the River Dee broadens as it moves from the higher uplands, entering a wide valley before dropping towards the lowlands.

\section{The contribution of the lithics}

The project impacts on wider scholarship through the contribution of its lithic artefacts in two particular fields: raw materials and typology. Although the use of a wide variety of local raw materials has long been recognised in lithic studies in Scotland (WickhamJones 1986), the contribution of rhyolite is new. The recognition of the knapping properties of this material, and its possible procurement from (albeit as yet unrecognised) local outcrops is a first for Mesolithic archaeology in Scotland. Extraction from outcrops in the Mesolithic has been recorded further south in the UK, for example at Maryport in Cumbria where Langdale tuff was collected from inland outcrops (Clarke \& Kirby forthcoming). It provides a clear example of the detailed local knowledge and intimate relationship with the land possessed by early communities.

Typologically, the presence of 'broad blade' microliths (Fig. 20) in the Chest of Dee assemblages is important because their place in Scottish assemblages has long been contentious. Often considered characteristic of Early Mesolithic activity in southern Britain, broad blade microliths are rare in excavated Scottish assemblages and have usually been found alongside (traditionally later) 'narrow blade' microliths at sites such as Morton, Fife (Coles 1971) and Nethermills, Aberdeenshire (Wickham-Jones et al. 2017). Imprecise dating means that these examples are generally assumed to represent mixed or transitional assemblages (cf Cramond et al. 2019). Recent modelling of dates associated with key artefact types in England has suggested that considerable typological change may be ascribed to the early centuries of the 8th millenium cal BC (Conneller et al. 2016), though emerging finds of broad blade material in Scotland has led others to date the Early/Later Mesolithic transition in Scotland to the second half of the 9th millennium (Ballin \& Ellis 2019).

Interpretation is hindered by controversy about the identification of narrow and broad blade forms, especially in so-called transitional assemblages (Waddington et al. 2017; Ballin \& Ellis 2019). At Chest of Dee, with its early dates, the presence of three clear broad blade microliths might not be surprising, except for the fact that none is associated with early dates. Only one occupies a secure context (TP3000), and that is a Mesolithic-Neolithic transitional date. Further evidence is necessary, both locally and generally. The broad blade microliths at Chest of Dee might be supportive of the early dates for part of the site and could simply reflect the way in which repeated occupation can disturb earlier surfaces. They might also be an indication of conservative tendencies, leading to the continued use of 'earlier' types and technologies in these upland landscapes in later periods, or they might reflect a hitherto poorly evidenced later date for broad blades in some parts of the UK. The recovery of pieces of a type that has previously been regarded as elusive in Scotland from the excavations at Chest of Dee is a further indication of the benefits to be gained from expanding our understanding of Mesolithic archaeology into the uplands.

\section{Exploring the Mesolithic-Neolithic transition}

The youngest 'Mesolithic' dates from Chest of Dee comprise three radiocarbon assays that date the upper fill of pit TP3000 to the period $3960-3780 \mathrm{cal} \mathrm{BC}$ (Range based on SUERC-28264, -50744, -50743; Table 1). The interpretation of this feature is interesting. The date is broadly contemporary with the earliest Neolithic activity along the lower stretches of the River Dee (eg Murray et al. 2009; Murray \& Murray 2014; Noble et al. 2016; Dingwall et al. 2019). Yet, the lithics within the fill comprise classically Mesolithic material, including both broad and narrow blade (traditionally early and late) pieces of flint and rhyolite. Indeed, the lithic assemblage from the site as a 
C. Wickham-Jones et al. NEW EVIDENCE FOR UPLAND OCCUPATION IN THE MESOLITHIC OF SCOTLAND

whole included little overtly Neolithic material apart from four Late Neolithic pieces from surface collection: two scrapers and two cores.

While the bulk of any lithic assemblage comprises generic material that could derive from any period, there was no indication, apart from the dating of TP3000, that activity on site might include an Early Neolithic presence. Elsewhere in Britain, later Mesolithic activity from upland locations has been shown to overlap in date with Neolithic sites in the immediate lowlands (Griffiths 2014), but this has not previously been demonstrated in Scotland. While the economic focus in the lowlands had shifted to agriculture, one explanation may be that lifestyles in the uplands were more nuanced so that seasonal patterns associated with a Mesolithic lifestyle perhaps continued or were pushed back into a restricted geographic region.

\section{Broadening our understanding of the upland contribution to Mesolithic lifeways}

The archaeology of the upper Dee evidences Mesolithic access to wider landscapes and resources and suggests that this upland landscape was not simply a network of routeways along which hunting and gathering groups passed on their way to somewhere more favourable. This landscape was more than a backdrop to human activity. It was a landscape in which people spent time, developing a web of integrated cultural behaviour, interconnecting along interlinked watercourses, and possibly over summit routeways. The minutiae of the fire spots along the river terrace at Chest of Dee is mirrored by the structural evidence at Caochanan Rudha and both contribute to wider interpretations.

Together, the sites add to the emerging evidence that Mesolithic Scotland encompassed more than the activities of coastal hunter-gatherers. Although a scattering of inland sites has been known for some time, such as Ben Lawers, Loch Doon, and Loch Garten (Affleck 1986; Saville 2007; Atkinson 2016) - the latter on the northern edge of the Cairngorm massif, at the other end of the passes along which the Dee and Geldie sites are located - the coastal bias of existing interpretations and the focus on shell middens and associated environments has long been cause for comment (Wickham-Jones 2009; Saville \& WickhamJones 2012).

The inhabitation of the landmass we now call Scotland clearly involved exploitation of a wide variety of ecozones, and both forested and upland environments were an important part of this. Information from sites such as Nethermills Farm (Wickham-Jones et al. 2017), Links House (Woodward 2008; Lee \& Woodward 2009), and the Tweed Valley (Mullholland 1970; Warren 2001) combine with that from the Cairngorms to highlight the significance of inland woodland and forest environments in the Early Holocene. Change, moreover, was chronological as well as spatial, and examination of these different sites facilitates consideration of possible activity sets and the evolving networks that linked them together over time.

Caochanan Ruadha is interpreted as providing evidence for human occupation around c. $6200 \mathrm{cal} \mathrm{BC}$, coinciding, at least partially, with the severe, shortlived climatic deterioration termed the ' $8.2 \mathrm{Ka}$ Event' (Warren et al. 2018). This period saw an abrupt drop in temperature of $2-3^{\circ} \mathrm{C}$, the formation of permanent snowfields and possibly the reformation of small valley glaciers in the Cairngorms (Harrison et al. 2014). The environmental impact included the initiation of blanket peat growth and changes to woodland dynamics (Dubois \& Ferguson 1985; Binney 1997; cf. Tipping et al. 2008). The human impact has still to be fully investigated. Though population models have suggested the collapse of coastal communities at this time (Wicks \& Mithen 2014; Waddington \& Wicks 2017), the interpretations remain controversial (Tipping in Dingwall et al. 2019, 319) and there is little data relating to the uplands.

At Chest of Dee, the dates are less conclusive. The calibrated age-ranges are not fine enough to verify activity during the ' $8.2 \mathrm{Ka}$ Event' and an absence of occupation during the period could equally be argued. Whether or not activity here coincided with the cold event, the presence of human groups in this upland landscape in the 7th millennium is a reminder of the inherent lifeskills and resilience of the Mesolithic community. This landscape was more than a larder for those who lived there. Though portrayed as remote and difficult today, life in the uplands was a routine element of the Mesolithic lifestyle. The survival of any group depended upon an intimate and long-term relationship with the land. In this sense, and whether or not settlement was frequent, this landscape was encultured (Mithen 2019).

Though lying below the tree line, sites such as Chest of Dee and Caochanan Ruadha also facilitate an examination of higher upland landscapes. A variety of activities are relevant, in addition to hunting practices. The procurement of stone, minerals, and other 
raw materials; the harvesting of foodstuffs; waterborne transport and riverine resources, all need to be considered in the upland context. So too cultural phenomena such as rites of passage, socialising and communication with other groups, the role of 'persistent places' (Barton et al. 1995), and the social and spiritual significance of natural features such as the Chest of Dee gorge. Interpretation of upland activities must become as nuanced as that of more extensively researched geographical locales. Hunting may have taken place, but that does not mean food procurement was the sole or dominant activity (Finlay 2000; Spikins 2000). Use-wear analysis at Caochanan Ruadha suggests this site saw the shooting of animals and processing of meat alongside the use of plant resources (Warren et al. 2018). The discovery of carbonised Taxus (yew) twigs here, possibly brought in from a considerable distance (cf Dickson 1993), may relate to use of its toxin in hunting strategies (Borgia et al. 2017; Borgia 2019), but the tranceinducing properties of its toxic vapour may also have played a socio-cultural role. At Chest of Dee people were, at least, procuring and working stone as well as cooking, resting by the fire, and perhaps fishing.

The future: Archaeology and landscape management in the upland zone in the 21st century

A compelling aspect of the evidence is that although there was small scale erosion, and the material was originally revealed by limited disturbance, in general the lithics and features are in situ. This is significant and has important implications for management of the historic environment.

The fragility of buried remains and their vulnerability to environmental change has been acknowledged (eg HES 2019), as has the increased threat posed to these fragile environments by predicted climate change (HES 2018). Upland landscapes exhibit extraordinary archaeological fragility, potentially exposed not just to threats such as flooding or fluvial erosion, but also increased drying and wildfire. Contemporary management and mitigation practices are vital, in this case providing the impetus for the initiation of the Upper Dee project by the National Trust for Scotland.

In Scotland, the overarching philosophy of contemporary land management views the uplands as 'wild land', devoid of significant human footprint. From the governmental perspective, this provides an ideal arena in which to tackle climate change and contribute to sustainable economic development. Both EU Directive requirements and Government climate change plans aim to expand woodland cover significantly in the coming decades, necessitating a considerable target of new woodland to be planted every year, and inevitably including upland planting at a large scale. As well as new planting, a variety of woodland regeneration schemes exist.

The depth of peat sealing many early prehistoric sites is well within viable limits for successful woodland expansion. This means that planting potentially threatens some of our best-preserved upland Mesolithic sites and landscapes - the vast majority of which remain to be discovered and for which we do not have a good knowledge base on which to predict site location. In terms of mitigation, the limited evidence for Mesolithic occupation in upland locations across Scotland to date has meant that archaeological impact assessments usually only consider upstanding monuments, predominantly medieval or later. Historic environment services at both state and local planning authority level need to consider the potential survival of fragile sites beneath the surface, over potentially vast tracts of land.

\section{CONCLUSIONS}

The Upper Dee Tributaries Project breaks new ground in providing evidence for the Mesolithic inhabitation of the uplands in inland Scotland. Despite a previous paucity of evidence, it is clear that hunting and gathering communities were familiar inhabitants of the Cairngorm landscapes from the 9th millennium BC, and that their lifestyle here was extensive, diverse, intense, and over considerable time depth. Undoubtedly many more sites remain to be discovered and their contribution to archaeology will be significant.

Expansion of our recognition of the Mesolithic record into the uplands offers clear archaeological benefits including a more comprehensive understanding of Mesolithic lifeways. In addition, the unique conditions of upland landscapes, where geomorphological processes differ from those of the lowlands, and past and present landuse encompasses different circumstances, mean that novel aspects of the archaeology are encountered. These can highlight elements that may be rare or poorly understood elsewhere and their investigation plays a significant role in broadening our interpretations of the archaeology. One immediate factor is the ephemeral nature of many sites, possibly 


\section{Wickham-Jones et al. NEW EVIDENCE FOR UPLAND OCCUPATION IN THE MESOLITHIC OF SCOTLAND}

representing aspects of Mesolithic lifeways that rarely survive elsewhere. Although archaeological material is harder to locate in the uplands, these locations hold considerable interpretive potential.

Exploring that potential is methodologically challenging. With regard to the specific case explored here, over $200 \mathrm{~km}$ of footpaths cross the Mar Lodge Estate and the areas where erosion extends into subpeat levels, with the potential to reveal evidence for early human activity, are scattered and generally small scale. While natural erosion provides further opportunities for discovery elsewhere, particularly along watercourses, our research suggests that active monitoring and prospection is necessary to highlight the opportunities to encounter new sites. There is a pressing need for fieldwork to locate and examine sites across the Scottish uplands, particularly in the context of landscape-scale management practices.

Though the scale of landscape across which sites have been found is thought-provoking, the implications are wider. The uplands are likely to have been tied into a much broader exploitation of the river valleys and landscapes leading from coast to mountain (Warren 2005; Wickham-Jones et al. 2017). The relationships between coast, river valleys, and uplands necessitate further research. While this project focuses on the upper reaches of the River Dee, another study now underway includes exploration of relationships between these sites and an intense concentration of Mesolithic activity along the lower reaches of the river. Implied connections with the North Sea coast to the east, including raw materials and other resources as well as transport systems, require investigation. Potential links with northwest Scotland remain to be explored, particularly given the location of the UDTP sites along major mountain routeways.

Reclaiming the uplands for the archaeology of early prehistoric populations opens exciting prospects to enrich our understanding of the full patterns of people's engagement with the landscape. As managers, this comprehensive understanding of past human behaviour is necessary to inform future land management strategies and ensure the survival of a fragile resource.

Note on radiocarbon dates: The radiocarbon dates presented in the text have been calibrated using the INTCAL13 calibration curve (Reimer et al. 2013), OxCal v4.3 (http://c14.arch.ox.ac.uk/) and the maximum intercept method (Stuiver \& Reimer 1986), with the endpoints rounded outward to 10 years.
Those that are shown in the figures have been calibrated by the probability method (Stuiver \& Reimer 1993), and where modelled are presented in italics with the endpoints rounded outward to 5 years.

Acknowledgements: The Upper Dee Tributaries Project partners are grateful for financial assistance received from the National Trust for Scotland, Aberdeenshire Council, the Society of Antiquaries of London, the Robert Kiln Charitable Trust, the Royal Archaeological Institute, and the Tony Clark Memorial Fund. As ever many people have contributed to the success of fieldwork including colleagues and students from the University of Aberdeen (Chest of Dee) and University College Dublin (Caochanan Ruadha); in particular we would like to thank Rick Knecht, Karen Milek, Oskar Sveinbjarnarson, Joe Cull, Bernard Gilhooly, Niamh Kelly, Rowan Lacey, Mark Powers, and James Redmond. Dr David Millward kindly helped with geological identification. This work would not have been possible without the support of the Trust's Property Manager David Frew and the Mar Lodge Estate team. Bruce Mann and two anonymous referees are thanked for helpful comments on the text.

\section{BIBLIOGRAPHY}

Affleck, T.L. 1986. Excavation at Starr, Loch Doon 1985. Glasgow Archaeological Society Bulletin 22, 10-21

Alley, R. \& Ágústdóttir, A.M. 2005. The 8K event: Cause and consequences of a major Holocene abrupt climate change. Quaternary Science Reviews 24, 1123-49

Atkinson, J.A. 2016. Ben Lawers. An archaeological landscape in time. Scottish Archaeological Internet Reports 62. https://doi.org/10.9750/issn.1473-3803.2016.62

Bailey, G. 2008. Mesolithic Europe: Overview and new problems. In Bailey, G. \& Spikins, P. (eds), Mesolithic Europe, 357-71. Cambridge: Cambridge University Press

Ballin T.B. \& Ellis, C. 2019. An undisturbed Early Mesolithic retooling station at Donich Park Lochgoilhead, Argyll, Scotland - right-handed and left-handed knappers. Archäologische Informationen 42. https://doi.org/10. 11588/ai.2019.0.69360

Bang-Andersen, S. 1987. Surveying the Mesolithic of the Norwegian Highlands - a case study on test-pits as a method of site discovery and delimitation. In Rowley-Conwy, P., Zvelebil, M. \& Blankholm, H.P. (eds), Mesolithic North West Europe: Recent trends, 33-43. Sheffield: Sheffield University Department of Archaeology \& Prehistory

Barton, R.N.E., Berridge, P.J., Walker, M.J.C. \& Bevins, R.E. 1995. Persistent places in the Mesolithic landscape: An example from the Black Mountain uplands of south Wales. Proceedings of the Prehistoric Society 61, 81-116

Bennett, K.D. 1996. Late-Quaternary vegetation dynamics of the Cairngorms. Botanical Journal of Scotland 48, 51-64

Binney, H.A. 1997. Holocene Environmental Change in the Scottish Highlands: Multi-proxy evidence from blanket peats. Unpublished PhD thesis, London: Guildhall University 
Borgia, V. 2019. The prehistory of poison arrows. In Wexler, P. (ed.), Toxicology in Antiquity, 1-10. New York: Academic Press

Borgia, V., Carlin, M.G. \& Crezzini, J. 2017. Poison, plants and Palaeolithic hunters. Quaternary International 427, 94-103

Brazier, V., Gordon, J.E., Hubbard, A. \& Sugden, D.E. 1996. The geomorphological evolution of a dynamic landscape: the Cairngorm Mountains, Scotland. Botanical Journal of Scotland 48, 13-30

Bronk Ramsey, C. 2009. Bayesian analysis of radiocarbon dates. Radiocarbon 51(1), 337-60

Clarke, A. \& Kirby, M. forthcoming. Tuff, flint, and hazelnuts: Final Palaeolithic and Mesolithic occupation at Netherhall Road, Maryport, Cumbria. Mesolithic Miscellany 28(1)

Coles, J.M. 1971. The early settlement of Scotland: Excavations at Morton, Fife. Proceedings of the Prehistoric Society 37, 284-66

Conneller C., Bayliss A., Milner N. \& Taylor, B. 2016. The resettlement of the British landscape: Towards a chronology of Early Mesolithic lithic assemblage types. Internet Archaeology 42. https://doi.org/10.11141/ia.42.11

Dickson, J.H. 1993. The yew tree (Taxus baccata L.) in Scotland - native or early introduction or both? Dissertationes Botanicae 196, 293-304

Dingwall, K., Ginnever, M., Tipping, R., van Wissel, J. \& Wilson, D. 2019. The Land was Forever; 15,000 years in north-east Scotland. Oxford: Oxbow Books

Dubois, A.D. \& Ferguson, D.K. 1985. The climatic history of pine in the Cairngorms based on radiocarbon dates and stable isotope analysis, with an account of the events leading up to its colonisation. Review of Palaeobotany o Palynology 46, 55-80

Edwards, K.J. 1996. The contribution of Tom Affleck to the study of the Mesolithic in Scotland. In Pollard, A. \& Morrison, A. (eds), The Early Prehistory of Scotland, 108-22. Edinburgh: Edinburgh University Press

Finlay, N. 2000. Deer prudence. Archaeological Review from Cambridge 17 (1), 67-79

Fontana F., Visentin D. \& Wierer U. 2016. MesoLife. A Mesolithic perspective on Alpine and neighbouring territories. Quaternary International 423, 1-4

Fraser, S., Noble, G., Warren, G., Tipping, R., Paterson, D., Mitchell, W., Clarke, A. \& Wickham-Jones, C.R. in press. The Upper Dee Tributaries Project: Finding the Mesolithic in the Mountains of Scotland. In D. Borić, D. Antonović, B. Mihailović, \& S. Stefanović (eds), Holocene Foragers in Europe and Beyond, 76-82. Belgrade: Serbian Archaeological Society

Griffiths, S. 2014. Points in time: The Mesolithic-Neolithic transition and the chronology of late rod microliths in Britain. Oxford Journal of Archaeology 33 (3), 221-43

Hamilton, W.D. \& Kenney, J. 2015. Multiple Bayesian modelling approaches to a suite of radiocarbon dates from ovens excavated at Ysgol yr Hendre, Caernarfon, north Wales. Quaternary Geochronology 25, 72-82

Harrison, S., Rowan, A.V., Glasser, N.F., Knight, J., Plummer, M.A. \& Mills, S.C. 2014. Little Ice Age glaciers in Britain: Glacier-modelling in the Cairngorm Mountains. The Holocene 24 (2), 135-40

Historic Environment Scotland (HES). 2018. https://www. historicenvironment.scot/archives-and-research/publications/ publication/?publicationId $=55 \mathrm{~d} 8 \mathrm{dde} 6-3 \mathrm{~b} 68-444 \mathrm{e}-\mathrm{b} 6 \mathrm{f} 2$ a $866011 d 129 a$

Historic Environment Scotland (HES). 2019. https://www. historicenvironment.scot/archives-and-research/publications/ publication/?publicationId=843d0c97-d3f4-4510-acd3aadf0118bf82

Jacobi, R.M. 1976. Britain inside and outside Mesolithic Europe. Proceedings of the Prehistoric Society 42, 67-84

Kirkbride, M., Everest, J., Benn, D., Gheorgiu, D. \& Dawson, A. 2014. Late-Holocene and Younger Dryas glaciers in the northern Cairngorm Mountains, Scotland. The Holocene 24 (2), 141-8

Lee, D. \& Woodward, N. 2009. Links House, Stronsay, Orkney (Stronsay parish), excavation. Discovery and Excavation in Scotland NS 10, 141

McClatchey, J. 1996. Spatial and altitudinal gradients of climate in the Cairngorms - observations from climatological and automatic weather stations. Botanical Journal of Scotland 48, 31-50

McEwen, L.J. 2000. The Geomorphological Character of The River Dee. Aboyne: Scottish Natural Heritage Report F99LF05

Maizels, J. 1985. The physical background of the River Dee. In Jenkins, D. (ed.), The Biology and Management of the River Dee, 7-22. Swindon: NERC

Mithen, S. 2019. Mesolithic fireplaces and the enculturation of Early Holocene landscapes in Britain, with a case study from western Scotland. Proceedings of the Prehistoric Society 85, 131-59

Mulholland, H. 1970. The microlithic industries of the Tweed Valley. Transactions of the Dumfriesshire \&o Galloway Natural History \& Antiquarian Society 47, 81-110

Murray, H.K. \& Murray, J.C. 2014. Mesolithic and Early Neolithic activity along the Dee: Eexcavations at Garthdee Road, Aberdeen. Proceedings of the Society of Antiquaries of Scotland 144, 1-64

Murray, H.K., Murray, J.C. \& Fraser, S.M. (eds). 2009. A Tale of the Unknown Unknowns: A Mesolithic pit alignment and a Neolithic timber hall at Warren Field, Crathes, Aberdeenshire. Oxford: Oxbow Books

Noble, G., Christie, C. \& Philip, E. 2016. Life is the pits! Ritual, refuse and Mesolithic-Neolithic settlement traditions in north-East Scotland. In Brophy, K., MacGregor, G. \& Ralston, I.B.M. (eds), The Neolithic of Mainland Scotland, 171-99. Edinburgh: Edinburgh University Press

Paterson, D. 2011. The Holocene History of Pinus sylvestris Wwoodland in the Mar Lodge Estate, Cairngorms, Eastern Scotland. Unpublished PhD Thesis, University of Stirling

Pears, N.V. 1968. Post-glacial tree-lines of the Cairngorm Mountains, Scotland. Transactions of the Botanical Society of Edinburgh 40, 361-94

Preston, P.R. 2013. New perspectives and suggested directions for future research on central Pennine Mesolithic 


\section{Wickham-Jones et al. NEW EVIDENCE FOR UPLAND OCCUPATION IN THE MESOLITHIC OF SCOTLAND}

lithic scatters. Archaeological Forum Journal: CBA Yorkshire 2, 1-20

Reimer, P.J., Bard, E., Bayliss, A., Beck, J.W., Blackwell, P.G., Bronk Ramsey, C., Buck, C.E., Cheng, H., Edwards, R.L., Friedrich, M., Grootes, P.M., Guilderson, T.P., Haflidason, H., Hajdas, I., Hatté, C., Heaton, T.J., Hoffmann, D.L., Hogg, A.G., Hughen, K.A., Kaiser, K.F., Kromer, B., Manning, S.W., Niu, M., Reimer, R.W., Richards, D.A., Scott, E.M., Southon, J.R., Staff, R.A., Turney, C.S.M. \& Plicht, J. van der 2013. IntCal13 and Marine13 radiocarbon age calibration curves $0-50,000$ years cal BP, Radiocarbon 55, 1869-87

Robertson-Rintoul, M.S.E. 1986. A quantitative soilstratigraphic approach to the correlation and dating of post-glacial river terraces in Glen Feshie, Western Cairngorms. Earth Surface Processes \& Landforms 11, 605-17

Saville, A. 2004. The material culture of Mesolithic Scotland. In Saville, A. (ed.), Mesolithic Scotland and its Neighbours, 185-220. Edinburgh: Society of Antiquaries of Scotland

Saville, A. 2007. Loch Garten. Discovery and Excavation in Scotland NS 8, 103

Saville, A. \& Wickham-Jones, C.R., (eds). 2012. Scottish Archaeological Research Framework (SCARF): Palaeolithic \& Mesolithic Panel Report. Edinburgh: Society of Antiquaries of Scotland

Spikins, P. 2000. Ethno-facts or ethno-fictions? Searching for the structure of settlement patterns. In Young, R. (ed.), Mesolithic Lifeways: Current research from Britain and Ireland, 105-18. Leicester: Leicester University Press

Spikins, P. 2002. Prehistoric People of the Pennines: Reconstructing the lifestyles of Mesolithic hunter-gatherers on Marsden Moor. Leeds: West Yorkshire Archaeological Service

Stuiver, M. \& Reimer, P.J. 1986. A computer program for radiocarbon age calibration. Radiocarbon 28, 1022-30

Stuiver, M. \& Reimer, P.J. 1993. Extended ${ }^{14} \mathrm{C}$ data base and revised CALIB $3.0{ }^{14} \mathrm{C}$ calibration program. Radiocarbon 35, 215-30

Sugden, D.E. 1971. The significance of periglacial activity on some Scottish mountains. Geographical Journal 137, 388-92

Tipping, R., Ashmore, P., Davies, A.L., Haggart, B.A., Moir, A., Newton, A., Sands, R., Skinner, T. \& Tisdall, E. 2008. Prehistoric Pinus woodland dynamics in an upland landscape in northern Scotland: The roles of climate change and human impact. Vegetation History \& Archaeobotany $17,251-67$
Waddington, C. \& Wicks, K. 2017. Resilience or wipe out? Evaluating the convergent impacts of the $8.2 \mathrm{ka}$ event and Storegga tsunami on the Mesolithic of northeast Britain. Journal of Archaeological Science: Reports 14, 692-714

Waddington C., Ballin T.B. \& Engl, R. 2017. Missing the point: A response to Conneller et al. (2016) and the mischaracterisation of narrow blade chronology in Britain. Mesolithic Miscellany 25, 26-33

Ward, G.K. \& Wilson, S.R. 1978. Procedure for comparing and combining radiocarbon age determinations: a critique, Archaeometry 20, 19-31

Warren, G.M. 2001. Towards a Social Archaeology of the Mesolithic in Eastern Scotland: Landscapes, contexts and experience. Unpublished $\mathrm{PhD}$ thesis, University of Edinburgh

Warren, G.M. 2005. Mesolithic Lives in Scotland. Stroud: Tempus

Warren, G.M., Fraser, S., Clarke, A., Driscoll, K., Mitchell, W., Noble, G., Paterson, D., Schulting, R., Tipping, R., Verbaas, A., Wilson, C. \& Wickham-Jones, C.R. 2018. Little house in the Mountains? A small Mesolithic structure from the Cairngorm Mountains, Scotland. Journal of Archaeological Science: Reports 18, 936-45

Waselkov, G.A. 1987. Shellfish gathering and shell midden archaeology. Advances in Archaeological Method and Theory 10, 92-210

Wickham-Jones, C.R. 1986; The procurement and use of stone for flaked tools in prehistoric Scotland. Proceedings of the Society of Antiquaries of Scotland 116, 1-10

Wickham-Jones, C.R. 2009. Footsteps in the north - archaeological understanding and the settling of northern Scotland and the islands. In Finlay, N. McCartan, S., Milner, N. \& Wickham-Jones, C.R. (eds), From Bann Flakes to Bushmills, 153-63. Oxford: Prehistoric Society Research Papers 1

Wickham-Jones, C.R., Kenworthy, J., Gould, A., MacGregor, G. \& Noble, G. 2017. Archaeological excavations at Nethermills Farm, Deeside, 1978-81. Proceedings of the Society of Antiquaries of Scotland 146, 7-55

Wicks, K. \& Mithen, S. 2014. The impact of the abrupt 8.2 ka cold event on the Mesolithic population of western Scotland: A Bayesian chronological analysis using 'activity events' as a population proxy. Journal of Archaeological Science 45, 240-69

Woodward, N. 2008. Links House, Orkney (Stronsay parish), fieldwalking, geophysics and excavation. Discovery and Excavation in Scotland NS 9, 137

\section{RÉSUMÉ}

Nouveau témoignage d'occupation des hautes terres au Mésolithique en Ecosse, de C.R. Wickham-Jones, G. Noble, S.M. Fraser, G. Warren, R. Tipping, D. Paterson, W. Mitchell, D. Hamilton et A. Clarke

Cet article discute les témoignages d'activité humaine épisodique dans les montagnes des Cairngorms d'Ecosse de la fin du 9ième millénaire au début du quatrième millénaire av.J.-C. Tandis que les paradigmes contemporains pour l'Europe mésolithique reconnaissent l'importance des environnements de hautes terres, les archives archéologiques pour ces zones ne sont pas aussi robustes que celles pour les zones de basses terres. Les résultats 
des fouilles à Chest of Dee, le long du cours supérieur de la rivière Dee, sont replacées dans un contexte plus étendu avec des fouilles publiées antérieurement dans la région. Une variété de types de sites met en évidence une relation sophistiquée entre les peuples et un paysage dynamique à travers une période de changement climatique. Les bénéfices archéologiques du projet comprenent la possibilité d'examiner des aspects innovants de l'archéologie conduisant à une compréhension plus globale de la manière de vivre du Mésolithique. Il nous offre aussi d'importantes leçons sur la survivance du site, les investigations archéologiques et la gestion des zones de hautes terres.

\section{ZUSAMMENFASSUNG}

Neue Hinweise auf die Besiedlung des Hochlands im Mesolithikum Schottlands, von C.R. Wickham-Jones, G. Noble, S.M. Fraser, G. Warren, R. Tipping, D. Paterson, W. Mitchell, D. Hamilton und A. Clarke

Dieser Beitrag diskutiert Hinweise für periodische menschliche Aktivitäten in den Cairngorm Mountains in Schottland vom späten 9. Jahrtausend bis zum frühen 4. Jahrtausend cal BC. Während gegenwärtige Paradigmen zum mesolithischen Europa zwar die Bedeutung von Hochlandregionen einräumen, ist die archäologische Datenlage für diese Regionen noch nicht so robust wie die für die Tieflandgebiete. Ergebnisse der Ausgrabungen in Chest of Dee am Oberlauf des Flusses Dee lassen sich mit bereits publizierten Ausgrabungen in der Region zusammenbringen. Eine Vielzahl an Fundplatztypen zeigt eine entwickelte Beziehung zwischen Menschen und einer dynamischen Landschaft in einer Zeit des klimatischen Wandels. Der archäologische Ertrag des Projekts umfasst die Möglichkeit neue Aspekte der Archäologie zu untersuchen und zu einem umfassenderen Verständnis mesolithischer Lebensweisen zu kommen. Es ermöglicht auch wichtige Einsichten in die Erhaltung von Fundplätzen, in archäologische Untersuchungsmöglichkeiten und in den Umgang mit der Hochlandzone.

\section{RESUMEN}

Nuevas evidencias de ocupaciones en zonas altas en el Mesolitico de Escocia, por C.R. Wickham-Jones, G. Noble, S.M. Fraser, G. Warren, R. Tipping, D. Paterson, W. Mitchell, D. Hamilton y A. Clarke

En este artículo se discute la evidencia sobre las actividades humanas periódicas en las montañas de Cairngorm en Escocia entre finales del IX e inicios del IV milenio cal BC. Aunque los paradigmas actuales para el Mesolítico Europeo reconocen la importancia de los entornos elevados, el registro arqueológico para estas áreas no es aún tan robusto como en las cotas más bajas. Los resultados de la excavación de Chest of Dee, en la cabecera del río Dee, se ponen en relación con un contexto más amplio a partir de las excavaciones previamente publicadas en el área. La gran variedad de sitios evidencia una relación compleja entre los grupos humanos y la dinámica del paisaje a lo largo de un período de transformaciones climáticas. Los beneficios arqueológicos del proyecto incluyen la capacidad para examinar los aspectos novedosos de la arqueología que conducen a una comprensión integral de las formas de vida mesolíticas. De la misma manera, también ofrece importantes lecciones sobre la conservación del sitio, la investigación arqueológica y la gestión de las zonas más altas. 